\title{
EVALUATING THE EFFICIENCY OF LARGE SCALE TRANSIT INFRASTRUCTURE PLANNING IN TORONTO ONTARIO: ISSUES OF GOVERNANCE
}

by

Michael Enzo Testaguzza

BA, University of Toronto, 2012

\author{
A Major Research Paper \\ presented to Ryerson University \\ in partial fulfillment of the requirements for the degree of \\ Master of Planning \\ in \\ Urban Development
}

Toronto, Ontario, Canada, 2014

C) Michael Enzo Testaguzza 2014 


\section{Author's Declaration}

I hereby declare that I am the sole author of this major research paper. This is a true copy of the major research paper, including any required final revisions, as accepted by my examiners.

I authorize Ryerson University to lend this major research paper to other institutions or individuals for the purpose of scholarly research.

I further authorize Ryerson University to reproduce this major research paper by photocopying or by other means, in total or in part, at the request of other institutions or individuals for the purpose of scholarly research.

I understand that my major research paper may be made electronically available to the public. 


\title{
[EVALUATING THE EFFICIENCY OF LARGE SCALE TRANSIT INFRASTRUCTURE PLANNING IN TORONTO ONTARIO: ISSUES OF GOVERNANCE]
}

\author{
(C) Michael Enzo Testaguzza 2014 \\ Master of Planning
}

in

Urban Development

Ryerson University

\begin{abstract}
This report analyzes the governance of large scale public transit infrastructure planning in the GTA. To accomplish this goal a comparative case study was carried out of the two most recent large scale public transit infrastructure provision plans in Toronto, the Network 2011 plan, and following iterations; and the Transit City aspects of the Big Move plan and subsequent iterations. Each case study consists of (1) a review of the history of each plan and (2) a review of the efficiency of the many iterations of the original plan within each case study. Through analysis of this data several characteristics of governance were associated with movement towards better and worse iterations from an efficiency perspective. These characteristics were used to inform recommendations regarding the future of transportation governance in the GTA.
\end{abstract}

Key words: Transportation Governance, Public Transit Infrastructure, Greater Toronto Area, Authority, Legitimacy, Financial Capacity 


\section{Acknowledgements}

I would like to acknowledge the support of both my first reader, Dr. David Amborski, and my second reader, Dr.

Raktim Mitra. Their advice, feedback, and ideas were essential in the creation and refinement of this document.

This research was supported by the Social Sciences and Humanities Research Council. 


\section{Table of Contents}

Title Page.

Author's Declaration

Abstract.

Acknowledgements

Table of Contents

Section 1 - Introduction

Section 2 - Literature Review.

Section 3 - Toronto Specific Context and Issues

Section 4 - Methodology

Section 5 - Section 5 - History of Transit Infrastructure Plans

Section 6 - Section 6 - Network Efficiency

Section 7 - Transit Governance That Works.

Section 8 - Recommendation

Section 9 - Appendices

Section 10 - Bibliography

\section{List of Figures}

Figure 1 - Case Studies and Iterations

Figure 2 - Graphic Analysis: Case 1 - Network 2011 et al. (Network 2011 iteration)

Figure 3 - Accessibility Summary 
Figure 4 - Accessibility/Cots Summary

Figure 5 - Connection with Land Use Designations Summary

Figure 6 - Connectivity Summary

Figure 7 - Efficiency Summary

\section{List of Maps}

Map 1 - Transit City Phase $1 \& 2$ alignment with underlying land use designations

Map 2 - Network 2011 Alignment and line segments

Map 3 - Let' Move Alignment and line segments

Map 4 - RTEP alignment and line segments

Map 5 - Conservative plan alignment and line segments

Map 6 - Transit City Phase $1 \& 2$ alignment and line segments

Map 7 - Ford MOU alignment and line segments

Map 8 - Transit City Phase 1 alignment and line segments

Map 9 - Transit City Phase 1 Plus Scarborough Subway alignment and line segments

Map 10 - Connections with Land Use Designations

\section{List of Appendices}

Appendix 1 - Summary of analysis of land use regulations

Appendix 2 - Sources used in the GIS analysis

Appendix 3- Sources used to determine the configuration of various iterations 
Appendix 5 - Census Tracts within Walking Distance of various iterations .................................

Appendix 6 - Employment Districts

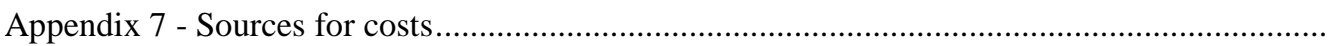

Appendix 8 - Land use Regulations

Appendix 9 - Graphic Representations of various iterations 


\section{Section 1 - Introduction}

The Greater Toronto Area (GTA) is currently experiencing rapid growth and decentralization (Bourne, 1989; Millward \& Bunting, 2007). However, the transportation networks in this region have yet to adapt. As such, building new public transit infrastructure will be important for the economic viability and quality of life in the region. However, it appears that the ability to build new infrastructure, as well as the quality of proposed plans, is currently constrained by governance structures in the GTA. Therefore, this report seeks to analyze the governance of large scale public transit infrastructure planning in the GTA; more specifically it seeks to understand what characteristics of the current governance system are producing positive plans from a network efficiency perspective, and what characteristics are producing negative results.

To accomplish this goal a comparative case study was carried out. The cases consist of the two most recent large scale public transit infrastructure provision plans in Toronto: the Network 2011 plan (TTC, 1985a), and following iterations; ${ }^{1}$ and the Transit City aspects of the Big Move plan (Metrolinx, 2008), ${ }^{2}$ and following iterations. ${ }^{3}$ The history of each case was studied to understand how plans changed over time and why. Additionally, the network efficiency of each iteration in each case was analyzed over time, to understand when plans became more efficient, and when less efficient. Efficiency was assessed based on three key aspects of efficiency; (1) accessibility, (2) connection to land use regulations, and (3) connectivity. ${ }^{4}$ Through analysis of the data mentioned above, several characteristics which were associated with movement towards more efficient iterations were noted. These

\footnotetext{
${ }^{1}$ Network 2011 was a transit expansion plan proposed by TTC staff in 1985 and approved in part by Metro council in 1986. It spawned a transit debate in the City, and in the region more broadly. This debate in turn led to numerous iterations of the original Network 2011 proposal being put forward by consecutive provincial governments. These include the Liberal government's Let's Move plan, the NDP's Rapid Transit Expansion Plan, and finally the Conservative government's plan which resulted in the construction of the Sheppard Subway.

${ }^{2}$ Transit City was a transit expansion plan developed and proposed by Toronto Mayor David Miller in 2006. Its four priority lines were subsequently included in the priority projects section of the provincial government's Big Move Plan. During the 2010 election in the City of Toronto, the Transit City plan came under attack by a number of high profile candidates. Eventual winner and Toronto Mayor Rob Ford reworked the Transit City aspects of the Big Move plan. This was followed by continuous debate in the public and in political spheres, which has spawned numerous iterations of the original plan.

${ }^{3}$ Iteration refers to subsequent versions of the original plan in each case study. However, in public transit planning there are always numerous iterations of the original plan proposed by different actors, and many have little chance of being carried out. As such, it was necessary to define very specifically which iterations would be studied; this is done in the methodology section. The general goal of this scoping was to limit analysis to iterations which were approved by at least one level of government with a financing plan in place.

${ }^{4}$ The means of measuring each aspect is further outlined in the Methodology section.
} 
characteristics were incorporated into recommendations for provincial politicians to consider with regards to the governance of large scale transit infrastructure planning.

This report is subdivided into eight sections; the first section being the introduction. The second section is comprised of a literature review, which attempts to position this study within the context of multiple academic debates. The third section provides an overview of transportation governance and funding in the GTA as well as an introduction to the transportation issues in the region. This section seeks to highlight the failings of the current system of transit governance in the GTA. The fourth section outlines the methodology used to collect data for the case studies. The fifth and sixth sections present the results of the two different segments of the case study; the historical review of each plan (5), and the review of the network efficiency of the iterations within each case (6). The seventh section provides an overview of the characteristics of governance that are exhibited in each case study and an analysis of the positive and negative dimensions of each characteristic. The final section (8) provides subsequent recommendations for the governance of large scale public transit infrastructure planning in the GTA context. 


\section{Section 2 - Literature review}

The governance of transportation in large city regions intersects with, and is related to, a number of academic and professional discussions surrounding competition in the global economy, regional identity, and regional governance.

There is general agreement that the transportation network is key to economic growth, and that as a important part of this network, the public transit system, and public transit infrastructure, must continue to adapt and change as a city region grows (Addie, 2010; OECD, 2009; Coleman, Kennedy, Maclean, Miller, \& Shalaby, 2005). Poorly planned or inadequate transportation networks lead to congestion (Coleman et al., 2005), and it is widely accepted that congestion can harm a city's economic prospects. It can lead to rising costs for local businesses (Coleman et al., 2005), and decreased productivity (HDR Corporation, 2008; Coleman et al., 2005; Addie, 2010; OECD, 2009). It can also reduce the size of the labour pool for employers, by limiting access to employees, which creates a distorted and suboptimal job market (OECD, 2009). It is well noted that congestion also affects citizen's work-life balance (HDR Corporations, 2008), and that the pollution generated affects their health (Meligrana, 1999; Toronto Medical Officer of Health, 2007). These quality of life issues are now seen as essential in attracting top level 'creative' talent to city regions (Slack, 2004). The creative class, those who innovate, are considered by many to be the main drivers of economic growth in the knowledge economy, and as such an inability to retain and attract them will result in poorer economic prospects for a city region (Keil \& Young, 2008; Bird \& Slack, 2007; Slack, 2004).

Congestion is in large part generated by excessive reliance on individual motorized transportation in large portions of the world (Coleman et al., 20005). Coleman et al. note that in order to produce a sustainable transportation network auto dependence must be reduced "without compromising urban mobility and accessibility," (2005, 406). How can public transit be part of the solution to the problem created by congestion? As mentioned above, reducing auto dependence without compromising accessibility is one way to reduce congestion. Therefore, in order to be part of the solution, new public transit infrastructure should strive to improve accessibility and ridership.

As urban form changes, public transit networks must adapt in order to continue to provide citizens with adequate access to different parts of a region (Mitra, 2013). Relative access from one point in a region to another is 
known as accessibility. Accessibility must be prioritized by politicians and professionals, since not all locations can be equally accessible. Different public transit corridors improve accessibility to different degrees by giving more or less people immediate access to the public transit system and giving these people more or less access to different destinations. Therefore, new public transit corridors should ensure that they provide the most accessibility in light of new and changing urban form.

As noted by Kennedy and Derrible (2010a) measures of accessibility using demographics and geography are common in studies of transportation corridors. However, they note that network design is another factor to be considered when studying transportation networks; they have demonstrated that it is positively correlated to ridership (Kennedy \& Derrible, 2010a; 2010b). As such, improving network design should increase ridership, and as such reduce auto dependence. In their work, Kennedy \& Derrible note that an essential component in the design of a network is the structure of that network, which is measured by connectivity and directness; "connectivity refers to the affluence and importance of links and node; directness determines the ease to travel within a network so as to avoid unnecessary transfers," (2010a, 276). Therefore, more connected and direct networks should be sought out when considering how to adapt the existing public transit network.

The preceding paragraphs demonstrate (1) the importance of the public transit network to economic growth and quality of life, and (2) that the public transit system must grow and adapt as urban form changes to improve accessibility and ridership. But how can the growth of urban transit infrastructure best be enabled? The academic literature/professional research surrounding ideal transportation governance structures is less conclusive. That being said there is one point of agreement, it is widely recognized that the region is an appropriate scale at which to deal with transportation decisions.

The reason for this is twofold. Firstly, this is because transportation functions on a regional basis; it does not stop at municipal boundaries. As such must be planned at this level if it is to function efficiently (Coleman et al., 2005; Bird \& Slack, 2007; Golden \& Knowles, 2012). Planning a regional network at a smaller scale is dangerous because the system will, by definition, cross municipal boundaries and produce positive and negative externalities /inter-jurisdictional spillovers (Golden \& Knowles, 2012; Bird \& Slack, 2007). These externalities in turn provide incentives for municipalities to under invest in transportation infrastructure (Kitchen, 2008), which produces an inefficient transportation network. In addition, Slack notes that a region body helps to "address fiscal disparities 
among municipalities, [and] resolve transportation and environmental coordination issues," (Golden \& Knowles, 2012, 77).

Secondly, it is generally agreed upon that a regional governance structure helps to legitimize action at the regional scale in the eyes of the public, and helps produce a regional 'spatial imaginary'. This in turn helps re-enforce demands for action on a regional scale. Boudreau (2007) notes that regions are constructed as political spaces, rather than existing naturally. Addie (2010) observes that these 'spatial imaginaries' are constructed through discourse and practice. As such, he notes, one way to foster the development of a regional spatial imaginary is to create regional institutions. Horak (2008), Boudreau, Hamel, Jouve, \& Keil (2006), and the OECD (2009) all recognize that when policy power is fragmented, as it often is at the regional scale, cooperation becomes a key challenge. Horak (2008) notes that coordinating the power necessary to carry out plans is often only obtained through cooperation, and that the more coordinated different actors original agendas are, the more likely they are to come to a mutually satisfactory outcome. A regional identity is one way to create similar policy agendas, by legitimizing action on that scale. This sentiment was shared by the majority of participants at a recent conference held at Ryerson University, entitled Governance Gridlock (Golden \& Knowles, 2012). In particular, several participants noted that transportation is a "potentially galvanizing issue that can be used to demonstrate how regional issues impact individuals," (Golden \& Knowles, 2012, 92).

The preceding paragraphs have demonstrated that it is generally accepted that the public transit network is key to economic growth, and must continue to adapt and change as a city region grows. As such, this study seeks to analyze the ability of governance structures in the GTA to produce efficient plans, which are sufficient to allow for continuous and purposeful growth of the existing network to meet changing needs. It has also shown that academics/professional researchers generally agree that the region is an appropriate scale at which to make transportation decisions. This provides the rationale for the scoping of this study at the regional scale, as well as a rationale for focusing on regional governance.

But what type of regional structure is best? Researchers generally agree that there is no one size fits all solution for governance; governance solutions must be specific to the regions they are in. This is largely attributed to the importance of context and place (Bird \& Slack, 2007; Hambleton \& Gross, 2007); and more specifically to 
divergent histories (Hambleton \& Gross, 2007), as well as cultural, geographical, and political factors (Coleman et al., 2005).

That being said, there has been extensive study regarding the different types of governance structures that have been employed in regional contexts globally. These governance structures can differ in numerous ways. For the purposes of simplification they have been broken down into 3 broad categories; authority, legitimacy/accountability, and funding/financial capacity. These categories will be used to assess the case studies in this report. Each of these criteria is briefly outlined below.

Authority

Authority refers to the distribution of decision making power. This refers to who has the legislative responsibility in certain policy fields. This responsibility can be shared between multiple institutions such as different levels of governments, $\mathrm{ABCs}$, and civil society organizations (externally decentralized), or can be centralized into one institution (externally centralized). The conception of authority used in this report also includes consideration of the centralization of decision making within each of the abovementioned institutions. For example, decision making power can be focused in the hands of a few people within an institution (internally centralized), or it could be broadly distributed (internally decentralized). A similar conception of authority is used in Hambleton \& Gross (2007), and in Coleman et al. (2005) (denoted as structure in this case).

\section{Legitimacy/Accountability}

In a democratic society, legitimacy is derived from free and open elections in which decision makers are chosen by citizens. The decisions of these politicians are then legitimate if they have been elected properly. ${ }^{5}$ As a result, decisions made by $\mathrm{ABCs}$ can at times lack legitimacy in the eyes of the public since these bodies are appointed rather than elected. This leads to a discussion about accountability, which refers to who answers to whom for making certain decisions. In a democratic society politicians are accountable to the citizens who elect them, and $\mathrm{ABCs}$ are generally responsible to the politicians who appoint them. The importance of legitimacy in public transit governance was acknowledged by Coleman et al. (2005) who note that some degree of spatial representation by

\footnotetext{
${ }^{5}$ It should be noted that Canada is a parliamentary democracy with a written constitution. The written constitution does put some boundaries on the power of the legislature, enshrining certain inalienable rights.
} 
democratically elected politicians is necessary; and by several participants at the Governance Gridlock conference including Crombie, Amborski, Broadbent, and Slack (Golden \& Knowles, 2012).

\section{Funding/Financial Capacity}

Funding refers to which institution is responsible for the funding of projects. Again this could be shared between multiple institutions or centralized. Financial capacity refers to the revenue generating capacities of different institutions in relation to their funding responsibilities. Again, the notion of different sources of funding, and different capacities to meet those obligations was noted by several participants at the Governance Gridlock conference (Golden \& Knowles, 2012), including all those mentioned above, as well as in the work of Coleman et al. (2005). 


\section{Section 3 - Toronto Specific Context and Issues}

The previous section demonstrated that the transportation network, and public transit in specific, is key to economic growth, that it must continue to adapt and change as a city region grows, and that the region is an appropriate scale at which to make public transit decisions. This provided the rationale for scoping this study at the regional scale, focusing on regional governance, and analyzing the ability of governance structures in the Greater Toronto Area (GTA) to produce efficient public transit infrastructure provision plans.

This however begs the following questions: what are the current governance structures in the GTA as they relate to public transit infrastructure provision, and have they produced the necessary infrastructure? Although these questions are dealt with in a more in-depth manner in the analysis section of the report, this section seeks to give the reader an understanding of the current state of public transit governance in the GTA and the outcomes which they have produced, in order to provide a rational for further study. In essence, this section of the report attempts to establish that there is in fact a problem to be studied.

\section{Governance Structures and Funding Sources}

Canada is a federal system, and for this reason the roles of all levels of government must be examined. The Federal government is not constitutionally responsible for urban transit infrastructure and has not used its spending power to involve itself in this sector. ${ }^{6}$ It should be noted that the Federal government has become more involved in the GTA recently, although their relative contribution remains small. As noted by Levy (2013) they committed to providing 1/3 of the cost of the Sheppard LRT and the Spadina-Allen Road subway and have also provided some money under the 2008-2010 stimulus program and other infrastructure funds (Soberman, 2006). ${ }^{89}$

\footnotetext{
${ }^{6}$ None of the 3 major transfers to the provincial governments (The Canada Social Transfer, $\$ 11.5$ billion; The Canada Health Transfer \$26.9 billion; and Equalization payments, \$14.7 billion in 2011-12) deal directly with infrastructure (Hjartarson, J., 2011).

${ }^{7}$ Many would argue that this is an insufficient arrangement considering the Federal government collects more money from taxes than all other governments (Federation of Canadian Municipalities, 2006). However, it should be noted that the Federal government does transfer a great deal of this money to the provinces (Flaherty, 2013). These transfers are largely unconditional and as such go into general revenue.

${ }^{8}$ Such as the Canada Strategic Infrastructure Fund (CSIF) and the Infrastructure Canada Program (ICP) (Soberman, 2006).

${ }^{9}$ They also contribute to urban transit infrastructure through Federal Gas Tax transfers, which unlike the other infrastructure funds is permanent as of 2011 (Infrastructure Canada, 2013).
} 
The provincial government is constitutionally responsible for local works and undertakings as laid out in section 92 of the Constitution Act, and as such provincial monies, largely from general revenue (Levy, 2013), are the key source of funding for large scale public transit infrastructure projects. Consequently, the provincial government makes a majority of the final decisions with regards to how that money is spent. ${ }^{10}$ In the province of Ontario, the power to decide how transit funds are allocated has been devolved to a degree, as Metrolinx (a regional, expert led, provincially appointed, special purpose body established in 2006) has been given the power to set priorities for transit infrastructure in the GTA, and is also responsible for operating GO Transit (Addie, 2010). However, decisions made by the Metrolinx Board are subject to approval from the Minister of Infrastructure (OECD, 2009; Krawchenko, 2011). As a result, the provincial cabinet retains final control over the Metrolinx's decisions.

The Province has recently announced a significant change in funding going forward; the remaining money needed for the Big Move Plan, not provided for through general revenue ( $\$ 34$ Billion), is to be funded by new revenue generating tools collected in the GTA and earmarked specifically for spending on transportation infrastructure (Metrolinx, 2013). Metrolinx and the province are currently looking at a number of revenue generating tools but no decision has been made with regards to selection or implementation. ${ }^{11}$

At the local level, there are several separate transit operating agencies in the GTA, as well as 4 upper tier municipalities (with 24 lower tier municipalities within their borders) and 1 single tier municipality. Municipal governments in the GTA are limited to two main own source revenue tools (the property tax and user fees) which are insufficient to pay for major transit upgrades (Golden \& Knowles, 2012; Kitchen, 2008). As such they rely heavily on provincial transfers for large scale transit infrastructure expansion. Each agency and municipality has an interest in the makeup of transit infrastructure within their boundary, and in the region more broadly. Therefore, each agency and municipality tends to lobby and negotiate with the provincial government and Metrolinx in order to

\footnotetext{
${ }^{10}$ Power in the Canadian parliamentary system is especially concentrated in the cabinet and more specifically with the Premier due to party discipline and the party system; the Premier's power of appointment and dismissal (to/from cabinet and $\mathrm{ABCs}$ ); executive federalism; and the concentration of technical resources/staff in the executive branches of government (Savoie, 2009; Savoie, 2006; Simpson, 2001; Savoie, 1999).

${ }^{11}$ The Transit Investment Strategy Advisory Panel (2013) suggested the following tools: a phased increase of the Gas tax, an increase in the corporate income tax, and dedicating the GTHA portion of the HST to transit infrastructure. The Liberal government stated that they would respond with specific revenue tools in their spring budget (Searle \& Nichols, 2013). To this date they have taken increases to the HST and gas tax off the table (CBC News, 2014; Morrow, 2014), but have emphasized that they still plan to establish "dedicated, ongoing, guaranteed funding," (Morrow, 2014) in the spring budget.
} 
have infrastructure provided within their jurisdiction according to their own interests (Addie, 2010). If Metrolinx and the province plan to locate transit infrastructure in these localities they are forced to negotiate with these individual agencies and municipalities because, with the exception of GO Transit, Metrolinx does not operate the infrastructure that they build. The result is that key public transit infrastructure expansion projects are subject to negotiation between a wide varieties of actors.

\section{GTA Specific Transportation Issues}

This abovementioned governing and funding arrangement has not produced adequate results in the GTA. The GTA has a long history of partial implementation and inaction in the realm of transit infrastructure provision. A myriad of plans have been proposed dating back to 1966 (the Metropolitan Transit Plan) (Levy, 2013); however no plan has been completely implemented as proposed. Over the same period, the GTA has undergone massive physical and demographic change, becoming a great deal larger and more decentralized (Bourne, 1989; Millward \& Bunting, 2007), and is one of a very few places in urban Canada that is currently experiencing growth. As early as 1989 Larry Bourne was noticing the GTA's emerging multi-nodal form and commented on its altering effects on established transportation patterns. In the same time period the IBI Group (1990) published a report for the Office of the GTA which concluded that transportation networks would need to adapt to changing regional urban structures and denoted that a multi-nodal urban form could emerge in the GTA. In recent years a multi-nodal form has indeed emerged, with several high density nodes appearing far from the central city; these nodes now occupy as much space as the central business district itself (Millward, Evolution, 2008; Millward, Patterning, 2008). As noted by Keil \& Young (2008), the existing transportation network does not visibly interact for the regional good, but is rather centred on serving each individual city in the region; and the rapid transit system is highly focused on serving the downtown core. Inaction on the transit infrastructure front coupled with physical and demographic change has produced a fundamental problem, a growing disconnect between the physical form of the city region and the transportation system which connects it. In short, transportation infrastructure, particularly transit infrastructure, has failed to keep up with the physical growth of the GTA region (OECD, 2009).

As a result, congestion on the region's roads continues to increase, filling the environment with pollutants, distorting the work-life balance, and costing the city region billion of dollars in lost business and inefficiencies (Toronto Medical Officer of Health, 2007; HDR Corporations, 2008; Kitchen 2008). Pollution from cars costs the 
city about 2.2billion dollars each year in Medicare (Toronto Medical Officer of Health, 2007), and congestion has been estimated to costs the regional economy 6 billion dollars each year in inefficiencies and lost opportunities (HDR, 2008). Lost time commuting also impacts the work-life balance of individuals in the region: meaning that individuals spend more time in their cars and less at home. This affects the quality of life of the regions inhabitants by reducing their leisure time and decreasing their access to amenities. This is problematic for a global city region such as the GTA because new theories around job creation and economic performance, in the vein of Florida's (2002) creative class argument, suggest that quality of life issues attract creative class workers, who in turn create wealth through innovation.

This section of the report demonstrates that the current governance systems in the GTA are not producing results from a public transit infrastructure perspective. The preceding section noted that growth of the public transit system will be a key to economic and demographic growth in the City. As such, new infrastructure will need to be provided in the GTA in the near future if the city region is to remain competitive, and clearly, governance models must be adapted in order to produce this change. But how what should change? How should new governance structures be organized, internally, and in relation to existing structures? This report seeks to begin to address some of these issues by analyzing what characteristics of transportation governance in the GTA have produced positive and negative results from a network efficiency perceptive, in order to shed light on possible characteristics that new/adapted governance structures in the GTA could adopt. The next section of the report seeks to outline how this analysis will be carried out. 


\section{Section 4 - Methodology}

\section{Research Design}

This study seeks to analyze the efficiency of recently planned large scale public transit infrastructure networks in the GTA, as well as the governance structures which produced them. To accomplish this goal a comparative case study was carried out consisting of the two most recent large scale transportation infrastructure provision plans in Toronto: the Network 2011 plan, and following iterations; and the Transit City aspects of the Big Move plan, and following iteration. A comparative analysis of case studies was selected because it allowed the researcher to explore variation in governance conditions and the effectiveness of the public transportation infrastructure outcomes.

Scoping

As noted above, the scope of this study is limited to the two most recent large scale transportation infrastructure provision plans in Toronto, and the iterations within them. This scope begs four questions:

(1) Is regional governance being studied if the scope is limited to Toronto? While Toronto does not represent the entire GTA, it is representative of the state of transportation governance in the GTA. All the key players in this governance system (Municipal politicians, Provincial politicians, and ABCs at both the regional and municipal scale) as well as all the key constraints (funding, popular support, strength and structure of government, desires of other regions etc.) are represented in this study.

(2) Why are transit initiatives of the recent past being studied? The reason is twofold. Firstly, transit infrastructure provision deadlock is a relatively recent phenomenon in Toronto (a problem of the last three decades). From 1954 to 1985 the majority of the Yonge, University-Spadina, and Bloor-Danforth Subway lines were built; as well as the Scarborough RT (Toronto Transit Commission, 2013). However, beginning in the 1980s, plans for further expansion of the rapid transit network produced very little in the way of results (Levy, 2013). If this is the case, wouldn't it be best to study the period which produced such great results (1954 to 1985), in order to understand how to produce them again? Unfortunately, the GTA context has changed significantly from the immediate post-war years. A more neoliberal approach to government has taken hold, bringing with it less spending from the public sector (Addie, 
2010; Boudreau et al. 2006), and the City of Toronto proper is now a much smaller part of a growing city region, and consequently must compete to a greater extent with other parts of the region for provincial funds. It is important to know what produces results in this new context; which is the second reason why the timeframe of this study is restricted to recent times.

(3) What is considered large scale transit infrastructure, and why is the study being limited to this type of infrastructure? LRT and Subway technologies are considered large scale public transit infrastructure. These technologies are being studied as they require significant capital outlays at their onset in comparison to expanding bus routes, provide significant ridership capacity, and operate at frequent intervals.

(4) What is meant by 'iterations within each case study'? Iteration refers to a subsequent version of the original plan in each case study. However, in public transit planning there are always numerous iterations of the original plan proposed by different actors; and many have little chance of being carried out. As such, it is necessary to define very specifically which iterations to study. For the purposes of this study, an iteration was defined as either (1) an original proposal within each case study or (2) any significant change which was approved by any level of government and had a funding plan in place. A significant change was considered a change that either added or removed a new line segment from a previous iteration. Removed from this analysis are long term visions and second priorities which did not receive dedicated funding, as this study seeks to understand what decision makers of the day actually planned to built, not what they hoped future governments would build. A list of the iterations studies within each plan is found below:

\begin{tabular}{|l|l|l|}
\hline \multicolumn{2}{|c|}{ Case Studies and Iterations } \\
\hline Case Study & \multicolumn{1}{|c|}{ Case 1 - Network 2011 et al. } & \multicolumn{1}{c|}{ Case 2 - Transit City et al. } \\
\hline \multirow{4}{*}{ Iterations } & 1) Network 2011 & 1) Transit City Phase 1\&2 \\
\cline { 2 - 3 } & 2) Let's Move & 2) Ford MOU \\
\cline { 2 - 3 } & 3) RTEP & 3) Transit City Phase 1 \\
\cline { 2 - 3 } & 4) Conservative Plan & 4) Transit City Phase 1 + Scarborough Subway \\
\hline
\end{tabular}

Figure 1

\section{Research Methods}

The study can be broadly broken down into two distinct sections. The first part of the study is largely qualitative. It entails a review of government, third party, and popular documents. Broadly, the goal of this section is 
to understand the history of each case study; how did the iterations change over time and why. This involved research related to who proposed the initial projects and why, and to what extent each project was implemented as originally proposed and why.

The second section of the study evaluated whether the changes noted above produced better or worse iterations from a network efficiency perspective. Given this goal, a mix of methods was used, with a greater focus on quantitative data. In order to understand the proposed alignment of various iterations, government, popular, and third party documents were used. The efficiency of each proposed iteration was assessed based on three aspects of efficiency; (1) accessibility, (2) connection with land use regulations, and (3) connectivity. These aspects were then considered in light of the assumed costs of each iteration, ${ }^{12}$ as stated by the project proponent. ${ }^{13}$

To quantify each aspect of efficiency several measures were used. Below is a brief description of these measures, as well as how they work to quantify each aspect of efficiency.

\section{(1) Accessibility}

In order to understand the accessibility of each iteration, three measures were used: the total population within walking distance of each new transit station, the average household income of this population, and the number of new transit stations within walking distance of an employment district. This was carried out using GIS (Geographic Information System) software, 2006 and 1981 census data, and employment data from the 2011 City of Toronto employment survey as well as the 1976 Central Area and Subcentres background study (data from 1974$){ }^{14}$ In order to measure these variables with a GIS package, an area of impact had to be determined. An 800 metres

\footnotetext{
${ }^{12}$ Costs refer to the upfront capital costs of each project. Operating costs were excluded because comparable data was not readily available and collecting this type of data was outside of the scope of the project.

${ }^{13}$ Approximating the capital costs of each proposal independent of the project proponent was not within the scope of this study. Using the project proponent's assumed cost introduces an inherent bias into the study as each proponent would have incentives to put forth the lowest possible cost estimate. This is not expected to negatively influence the results of the study since it is assumed that each proponent would be subject to the same incentives in this regard. The final results are skewed to the extent that certain actors underestimated their costs to a further extent than the average actor.

${ }^{14}$ This employment data was the closest data to the Network 2011 case study time frame that could be identified. The results are biased by use of this data set to the extent that employment concentrations changed between 1974 and the 1985-1995 periods.
} 
buffer from subway stops and an 600 metre buffer from LRT stops were identified. ${ }^{15}$ The area of impact was determined to be the geographic bounds of a census tract whose boundary intersected with or fell within the buffer.

The buffer approach has many limitations that should be noted here. First, the assumption that the entire population of a census tract which intersects the buffer has access to the station is counterintuitive. This is because people that are not within the buffers are still considered to have access, whereas the theory behind the buffer is that it represents how far people are willing to walk to get to transit of this order. In addition, the ability of people to access the station via car and bus is not analyzed using this method. As such the number of people within walking distance of each proposal is useful for comparison between iterations but is not particularly useful outside of this context (for example for potential analysis of ridership). Secondly, the exact location of stations is approximate since final construction/location data could not be obtained in all cases. Where this was the case, the location of stations was assumed to be directly above the intersection of the stop name and the relevant line alignment.

How do these measures quantify accessibility? By measuring the total population within walking distance of each station the study was able to assess how many people would have immediate access to each proposal without use of another mode of transportation, a rough proxy for accessibility. Studying the average income of the population within walking distance produces an understanding of the economic situation of the population served. This is particularly important because, as Burda and Haines (2011a) note, access to public transit helps low income individuals access more potential jobs, and thereby can improve economic performance. In this vein, an understanding of the proposals access to employment districts was also studied using the 2011 City of Toronto employment survey as well as the 1976 Central Area and Subcentres background study (data from 1974). Each of these studied defined employment districts. The number of stations within walking distance of an employment

\footnotetext{
${ }^{15}$ There is no definitive buffer size for LRT and subway stations identified in the academic literature. It is however, well noted that people are willing to walk further to transit which provides higher frequency service (Alshalalfah \& Shalaby, 2007; Daniels, R., \& Mulley, C., 2013). To reflect this fact different buffer sizes were selected for the two modes of transit. 800 metres was a frequently sighted number for rail whereas $400 \mathrm{~m}$ was frequently cited for bus (see El-Geneidy, Grimsrud, Wasfi, Tétreault, \& Surprenant-Legault (2014) for a list of examples). As such 800 metres was selected as the buffer size for subway stations. Zhao \& Deng (2013) noted that there was a 200-300m premium on underground rail transit in comparison to BRT. Zhao \& Deng (2013) and Guerra, Cervero, \& Tischler(2011) noted that on average the buffer used for LRT systems in Canada was between $300 \mathrm{~m}$ and $900 \mathrm{~m}$. This helped generate the $600 \mathrm{~m}$ buffer, which sits in the middle of the $300-900 \mathrm{~m}$ range and is $200 \mathrm{~m}$ less than the buffer used for subway technology.
} 
district (as defined by each source) was ascertained using the abovementioned GIS buffer. ${ }^{16}$ The more stations within walking distance of an employment district, the more accessible employment via rapid transit was assumed to be.

\section{(2) Connection with Land Use Regulations}

In order to understand each proposal's connection with land use regulations, land use designations from relevant Official Plans were used. For the Network 2011 case study the 1981 Official plan for the urban structure was used, and for the Transit City Case study the 2010 Toronto Official Plan. This process began with an analysis of the designations contained within the urban structure maps of each plan. This analysis produced an understanding of which land use designations in each Official Plan were transit supportive, and therefore which uses would be ideal for new transit to be located near. Transit supportive designations were considered ones which favoured intensification, mixed use development, and pedestrian oriented development (See Appendix 1 for a summary of this analysis). Following this, each iteration was overlaid atop the relevant urban structure map (See Map 1). Because each plan had different designations and layouts, the results of each analysis differ. The 1981 Official plan

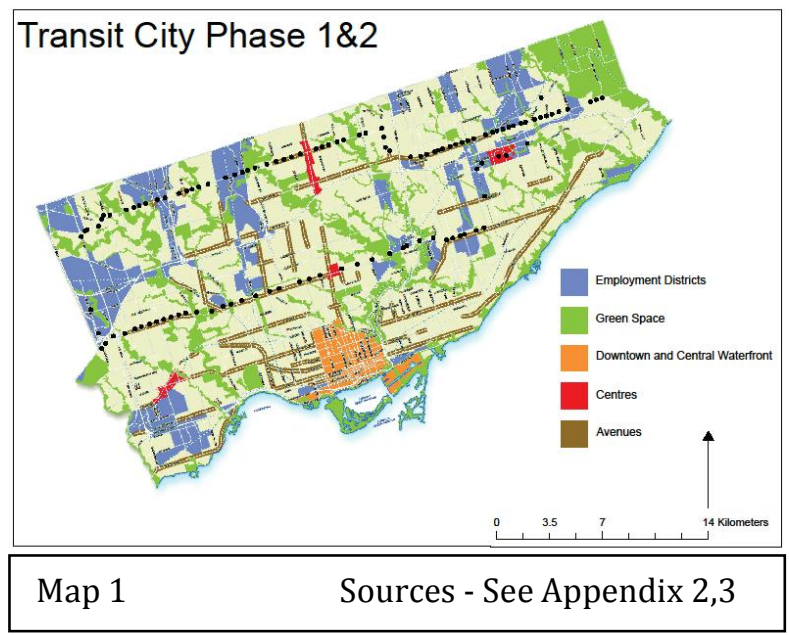
had only 3 designations: the Central Area, Major Subcentre, and Minor Subcentre. As such line segments did not run along, but generally to, or through, these areas. Therefore, the number of Central area, Major Subcentres, and Minor Subcentres reached or intersected by a proposed iteration was counted. The 2010 Toronto Official Plan was more difficult to assess because not only were Centres and Employment Districts designated, but so were Avenues, which run along corridors. As such, a simple count was not possible. Instead the predominant designations along each proposed transit corridor were listed, and the transit supportive designations highlighted. Proposals which avoided non-transit supportive designations to the greatest extent were considered the most transit supportive.

\footnotetext{
${ }^{16}$ The fact that each source defines an employment district differently will bias results to a degree. The level of bias is not expected to be to great because this data is to be compared within case studies rather than between them. What is compared between the case studies is the two trends rather than the raw data itself.
} 
Analyzing Official Plans was done in order to understand if land use regulations were coordinated with the proposed transit investment. Land use regulations provide a view into the future accessibility of each iteration. For example, if a corridor has policies which promote high density, mixed use, pedestrian supportive development, it will likely be accessible to more people and provide access to more jobs than when it was originally created. Alternatively, if policy promotes stability or low density development the current accessibility is unlikely to change.

It should be noted that potential benefits to accessibility from land use regulations will only be realized if development occurs within these corridors. Several factors can put a halt to development pressure, many of which are noted in the IBI Group's (1990) Greater Toronto Area Urban Structure Concepts Study. Consequentially, this variable, while important, should be considered secondary to accessibility at the point of construction, as it is more speculative in nature.

\section{(3) Connectivity}

In order to calculate connectivity several measures were used. Firstly, structural connectivity was measured using the using the Rho index ( $\rho$ ). As noted by Kennedy \& Derrible this index attempts to "calculate the influence of transfer stations to facilitate traveling," (2010b, 45). It was found to be positively correlated with ridership (Kennedy \& Derrible, 2010a). In order to calculate the degree of connectivity the Gamma index $(\gamma)$ was used (Kennedy \& Derrible, 2010a). This provides and understanding of "how much a network is connected relative to how much it could be connected," (Kennedy \& Derrible, 2010a, 282). As noted by Rodrigue et al. (2009), this measure is most often used to analyze the progression of a network over time. A third element of connectivity relates to directness; it was also found to have a positive, linear correlation to ridership (Kennedy \& Derrible, 2010a), and is measured using the Tau index $(\tau)$.

These three methods were used because they analyze different aspects of connectivity. The Rho index takes into account the importance of transfer stations (with special emphasis on stations that allow for transfers to multiple lines, which decreases time and increases choice by allowing for more direct travel). The Gamma index takes into account the importance of multiple connections between vertices (which produces service redundancies; allowing for greater choice and the ability to bypass delays). Lastly, the Tau index takes into account the different number of 
lines in relation to the maximum number of transfers required, as transfers increase, the value of the result declines, representing the negative impact of necessary transfers on ridership.

Each of these calculations involves the use of graph theory. Graph theory involves analyzing a transportation network as a graph, with transfer and terminus station representing vertices, and the lines connecting those representing edges (See Figure 2 for an example).

The calculation for each of the indexes above is found below:

$\begin{array}{lll}\text { Measures of Connectivity } & \text { Range } & \text { Calculation } \\ \text { 1) Rho index } & 1 \leq \rho \geq 1 \text {; higher is more connected } & \rho=(\text { vtc-em }) / v t \\ \text { 2) Gamma index } & 0-1 \text {, with } 1 \text { being completely connected } & \gamma=\mathrm{e} / 3(\mathrm{v}-2) \\ \text { 3) Tau index } & 1 \leq \tau \geq 1 \text {; higher is more direct } & \tau=\mathrm{Nl} / \delta\end{array}$

where:

$\mathrm{Nl}=$ Number of Lines (ie. Bloor-Danforth Line)

$\mathrm{v}=$ Number of Stations

$\mathrm{vc}=$ Number of Terminal Stations

$\mathrm{vt}=$ Number of Transfer Stations

$\mathrm{e}=$ Line segments connecting terminal or transfer stations with one another.

es $=$ A line segments used by one line. (eg. Kipling to Spadina)

em $=$ A line segments used by two lines. (eg. Spadina to St. George)

$\delta=$ The maximum number of transfers that a rider could possibly make on a system (eg. To go from Scarborough to Sheppard a patron would need 3 transfers).

$\mathrm{vtc}=$ The number of transfer possibilities. This is the sum of all possible transfers from each transfer station. ${ }^{17}$

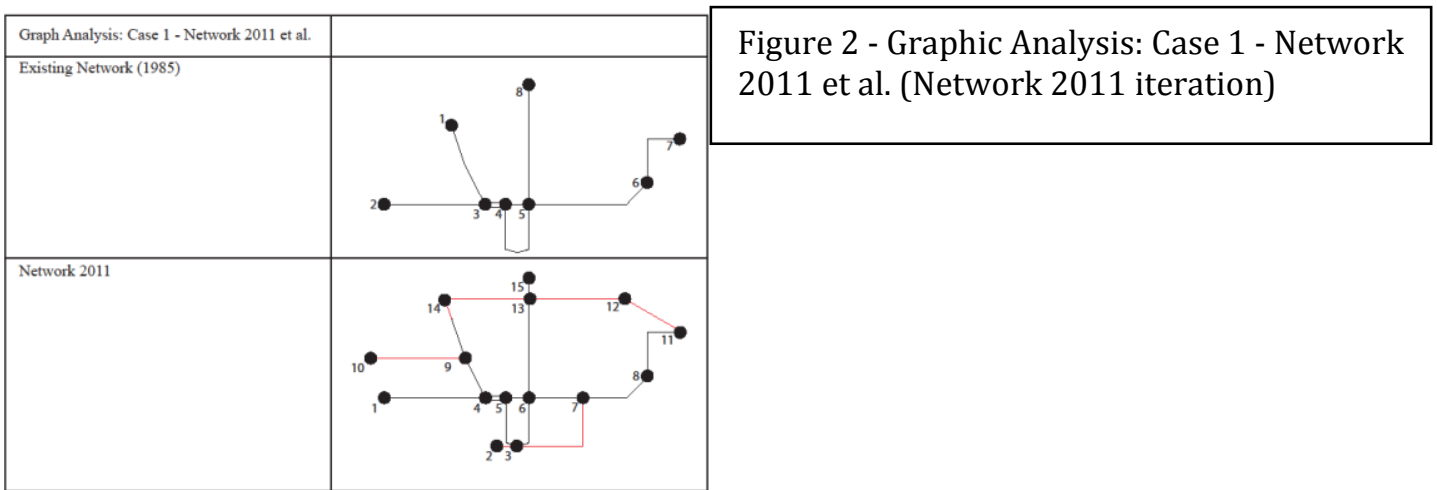

\footnotetext{
${ }^{17}$ For a more in-depth description of each variable see Kennedy \& Derrible (2010a; 2010b).
} 


\section{Section 5 - History of transit infrastructure plans}

This section of the report aims to provide an understanding of the history of each infrastructure expansion plan; to understand how the plan changed over time and why. As such, it will provide a history of each case study, summarizing who proposed the initial iteration and why, and what different iterations appeared thereafter, and why.

\section{Case 1 - Network 2011 et al.}

\section{Iteration 1 - Network 2011}

Network 2011 was based on 3 detailed studies carried out by TTC staff (Toronto Transit Commission, 1985a). These reports and the ensuing recommendations, known as Network 2011, were carried out at the behest of Metro Toronto Council. Network 2011 recommended the construction of 3 new subway lines by 2011 (Get Toronto Moving Transportation Committee, 2014a). Construction of these three lines was to be

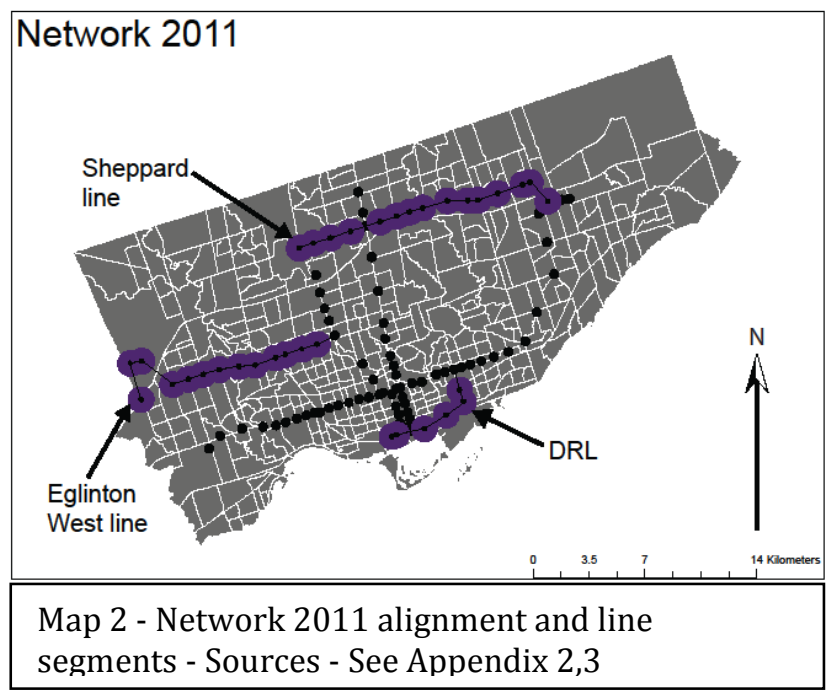

phased, with the Sheppard line receiving priority, followed by the Downtown Relief Line and the Eglinton busway; which would later be upgraded to a full subway (Levy, 2013; Get Toronto Moving Transportation Committee, 2014a; Bow, 2011). This transit expansion plan was meant to support the 1980 Metro Official Plan, which directed population and employment growth away from the downtown core towards Subcentres in the inner suburbs; specifically North York and Scarborough (Frisken, Bourne, Gad, \& Murdie, 2000; Get Toronto Moving, 2014b; Municipality of Metropolitan Toronto, 1981). In order to ensure that transit remained a competitive option in Toronto, rapid transit would be brought to these Subcentres (Toronto Transit Commission, 1985a). The Sheppard subway was meant to connect North York City Centre and Scarborough City Centre to each other and to existing subway system (Bow, 2013). However it was also meant to improve transit conditions on Sheppard (this bus was the busiest in the city) (Toronto Transit Commission, 1985a), to relieve congestion on the 404/DVP (Get Toronto Moving Transportation Committee, 2014), and to relieve congestion on the Bloor-Danforth Line (Bow, 2013). The 
main purpose of the Downtown relief line (DRL) was too relieve congestion at Bloor-Yonge Station (Levy, 2013; Bow, 2013). The Eglinton subway was meant to connect York Centre to the existing subway system and to the growing region of Peel, as well as to divert trips from the Bloor-Danforth line to ease congestion at St. George (Toronto Transit Commission, 1985b).

Network 2011 sparked intense negotiation in Metro Council. The negotiation was largely about phasing, with different factions in Metro pushing for their portion of the plan to be built first. York and Etobicoke councillors argued that not enough attention was being paid to potential growth along the Eglinton Corridor, and argued for it to be built sooner, and as a subway from the start (Orr, \& Perry, 2010). However, these two boroughs had only 8 of the 40 votes on Metro council (Smith, 1986a; Smith, 1986b). The fact that they were also supported by Peel Region did not matter because Peel Region was not part of Metro Toronto (Smith, 1986a). Scarborough and North York Councillors argued for the Sheppard line to be built first and in its entirety, rather than in the phased manner suggested (Braber, 1994). Lastly, downtown councillors argued for the phasing to remain as was suggested (Smith, 1986b), although some did argue for the DRL to be removed entirely because it would create further development pressure downtown, was explicably prohibited in the official plan, and would not serve the local community (James, 1993; Bakht, 2013; English, 2012; Smith, 1986b).

In June of 1986 Metro council approved the first phase of the plan, the subway line along Sheppard Ave. from Yonge St. to Victoria Park Ave. (Osbaldeston, 2011; Bakht, 2013; Get Toronto Moving, 2014a).

\section{Iteration 2 - Let's Move}

Let's Move was an assertion of priorities by the provincial government, after years of study regarding transportation needs in the GTA (Bakht, 2013), and in response to the City's Network 2011 plan (Soberman, 1997a). It was announced in April 1990, (Frisken et al., 2000) near the end of the Liberal governments 1987-90 term in office (Bow, 2013). It was

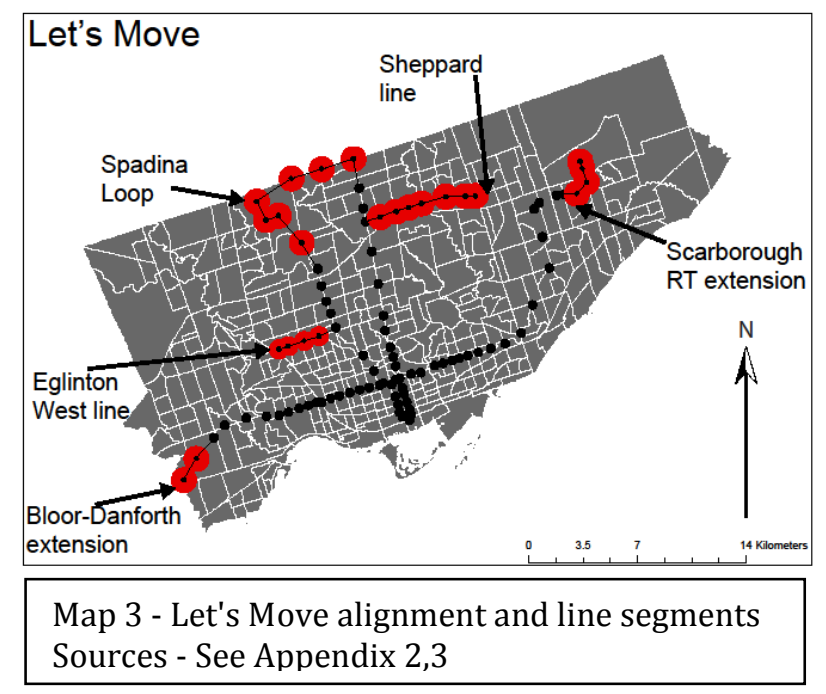


comprised of a shortened version of the Sheppard and Eglinton lines (Eglinton was converted to LRT technology) (Osbaldeston, 2011), as well as a subway loop connecting the Spadina and Yonge lines via Steeles Ave., an extension of the Bloor Danforth line to Sherway Gardens, and an extension of the Scarborough RT to Sheppard and Markham Road (Bow, 2013). The plan way expected to cost $\$ 4.6$ billion (Bow, 2013; Byers, 1990).

Why did this chance occur? Infighting between the constituent municipalities of Metro Toronto over the Network 2011 plan created uncertainty at the provincial level; which, when combined with demands from other regions surrounding Toronto for additional funds, led the Liberal provincial government to delay announcing funding for the project while they assessed transportation needs in the GTA more broadly (Soberman, 1997a). The province was "concerned that there was no exterior connections to the broader TO region in priority lines," (Osbaldeston, 2011, 72). It was also believed that the Liberals were wary of the cost of the plan after being recently elected. In fact, cost is often cited as one of the main reasons for the exclusion of the DRL from the Let's Move plan (Get Toronto Moving, 2014a). In addition, the line appeared to have few friends. As mentioned above it was not strongly supported by Downtown Toronto Councillors, and was outright feared by inner suburban councillors, who believed that it would have had a detrimental effect on the growth of the Subcentres (Levy, 2013) (at this time suburban councillors made up a majority of Metro Council (Frisken et al., 2000)). For all these reasons, the provincial government put the Network 2011 iteration under review (Bow, 2013; Orr, \& Perry, 2010).

The lines within the Let's Move iteration were selected by the provincial government and preferred to the Network 2011 iteration because they provided better connection with the rest of the region. Many of the lines in this plan (the Spadina loop and the Bloor-Danforth extension) reached to the municipal boundaries (Frisken et al., 2000; Get Toronto Moving, 2014a). Crowding on the Y-U-S line remained an issue and was to be dealt with by the Spadina loop, which would allow trains to run more frequently by eliminating the need to turn around (English, 2012). However many argue that Let's Move was announced for political reasons, to garner voter support in the GTA; it was announced just prior to a provincial election (Gormick, 1990; Bow, 2013).

After the announcement, Etobicoke and York councillors continued to argue that the Eglinton corridor was just as important as Sheppard and should see a full subway (Get Toronto Moving, 2014a). However, there was less debate about this plan than its predecessor, as the NDP were elected in September of 1990 (Osbaldeston, 2011), and began to formulate their own plan. 


\section{Iteration 3 - The Rapid Transit Expansion Plan (RTEP)}

The Rapid Transit Expansion plan proposed to build truncated versions of the Sheppard (to Don Mills) and Eglinton (to York Centre) Subways.

When the NDP took over from the Liberals they promised to honour the Let's Move plan, however no funding was announced to support the projects (James, 1993). Instead, upon winning the 1990 election, Bob Rae's NDP government began to

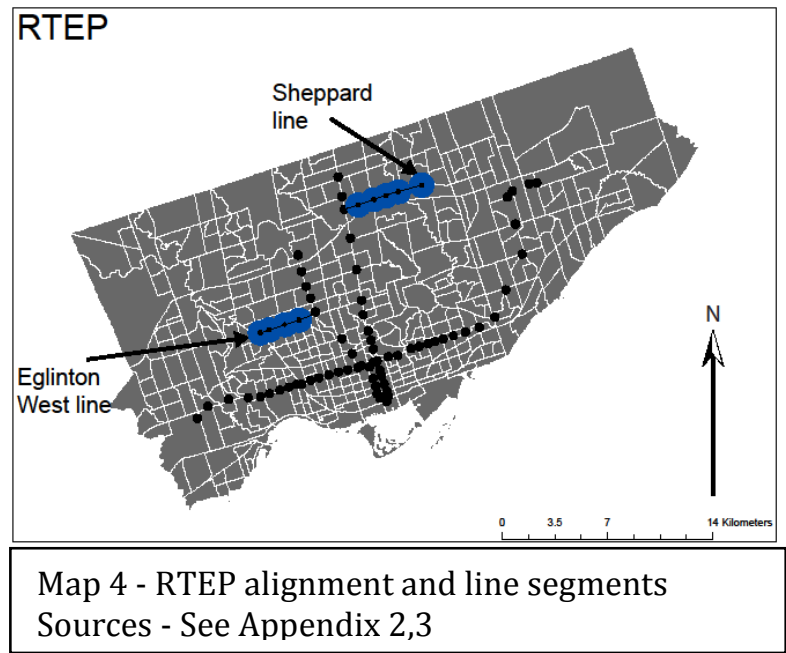

review Let's Move (Orr \& Perry, 2010). However, the NDP's plan, known as the RTEP, was not announced until February 1993, near the end of their Mandate (Bow, 2013). The NDP committed to funding 75 percent of 4 of the 6 major lines from Let's Move (Byers, 1990; Toronto Transit Commission, 1995); supporting a subway along Sheppard to Don Mills, a subway along Eglinton to York Centre, a Spadina extension to Steeles, and the Scarborough RT extension to Markham Road at Sheppard. These were all to occur simultaneously (Levy, 2013). Metropolitan Toronto, who was to pay the remaining 25 percent of the costs, argued that it could not afford its portion of the cost of all four lines (Soberman, 1997a), and in March 1994 agreed to the construction of the Sheppard and Eglinton subways only, at a cost of roughly $\$ 1.9$ billion (Toronto Transit Commission, 1995; Bow, 2013; Soberman, 1997a). The remaining lines would have to await adequate funding (Toronto Transit Commission, 1995).

As seen above, one of the major factors influencing the NDP's, and later Metro Council's, scaled down RTEP were fiscal constraints produced by a recession in the early 1990's (Bow, 2013). However, the lines selected as part of the RTEP's were heavily influenced by politics, not economics. Note that in the four selected provincial lines there was a benefit for each part of Metro Toronto (Bow, 2011). Additionally, some have argued that the Rae government choose to support subways in both North York and York to appease residents and politicians on both sides of the debate (Get Toronto Moving, 2014a). York and Etobicoke had especially applied a great deal of pressure on the province via Metro Council by forming "a voting block agitating that the Eglinton rapid transit line be built as a subway from the start" (Bow, 2011). As English (2012) notes, the Rae government was "particularly 
responsive to complaints about the unfairness of Eglinton West," because "the Premier's riding was located in York." With regards to the selection of the final two subway lines supported by Metro Toronto, the political manoeuvring becomes even clearer. Metro Chairman Allan Tonks supported the Sheppard and Eglinton lines (Coutts, 1994). Coincidentally, the Eglinton line ran through his ward as well as through TTC chairman Mike Colle's ward (Barber, 1994). Support for the Sheppard line was garnered by the Mayor of North York, Mel Lastman, who's City the line ran through.

Interestingly enough, economics was used to justify the selection of these two lines. It was argued that the increased tax base provided by these subways would help pay for them in the long run, and as such they were not deemed to be 'too expensive' by a majority of Metro Councillors (Coutts, 1994). The other main argument in favour of these two subways was the fact that they would create a great deal of jobs. Some argue that this fact, rather than an analysis of the impact of each subway on the transportation system, convinced politicians to approve the two lines (Coutts, 1994).

Iteration 4 - The Conservative Plan

On June 26, 1995 the Ontario

Progressive Conservative (PC) party defeated the NDP and came into power under Mike Harris. Part of their election platform involved steep cuts to provincial spending (Soberman, 1997a; Bakht, 2013). On July 211995 the PCs announced cuts to infrastructure, among other things, and said the government would proceed with transit projects in a phased manner, beginning with

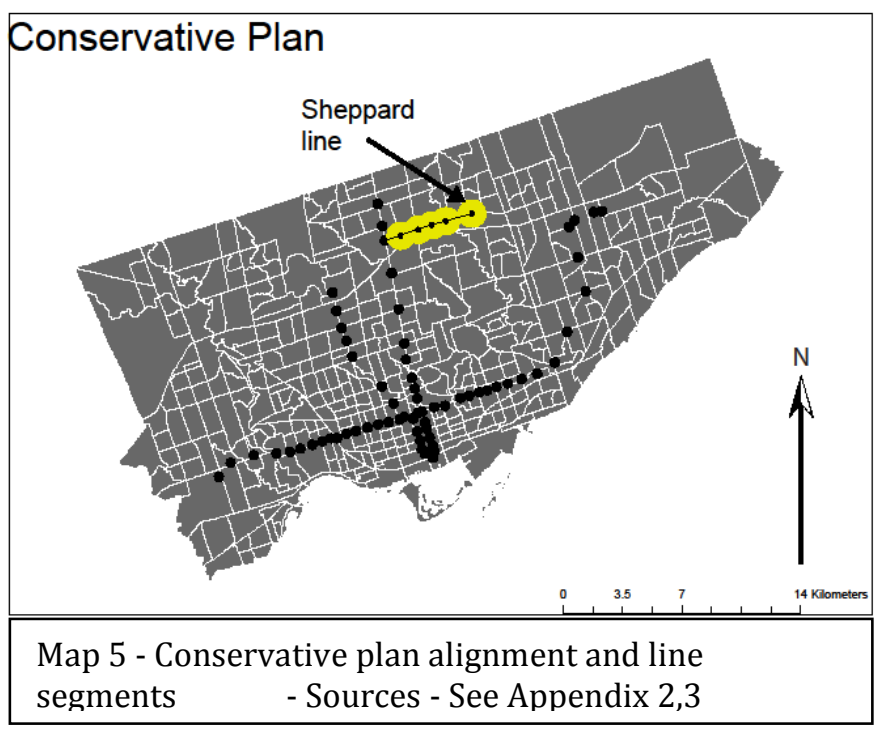
the Sheppard subway (Bradburn, 2012; Levy, 2013). The intense lobbying of Mayor Mel Lastman has been credited with saving the Sheppard subway by multiple sources (English, 2012; Levy, 2013; Adel \& Bow, 2012). The fact that Mel Lastman was a lifetime Tory, and that "voters along the Sheppard line provided the new government with its attorney-general, Charles Harnick," (Bradburn, 2012) could have improved Lastman's bargaining position. It has 
also been argued by Levy that Lastman's lobbying was backed by "technically based advocacy," $(2013,167)$. The recently elected Mayor of the City of York, Frances Nunziata, and several local residence associations were not as successful in their bid to save the Eglinton subway (Bradburn, 2012). The Eglinton project was deferred indefinitely, and never built (Bradburn, 2012).

\section{Case 2 - Transit City et al.}

\section{Iteration 1 - Transit City Phase 1\&2}

The Transit City plan was a stark break from Network 2011 and its related proposals as the emphasis changed from subway expansion to the use of LRT technology. In 2006 City of Toronto Mayor David Miller was up for re-election and on October 24, 2006 he unveiled his vision for transit expansion based on Light Rail Transit technology (CNW Group, 2006). On

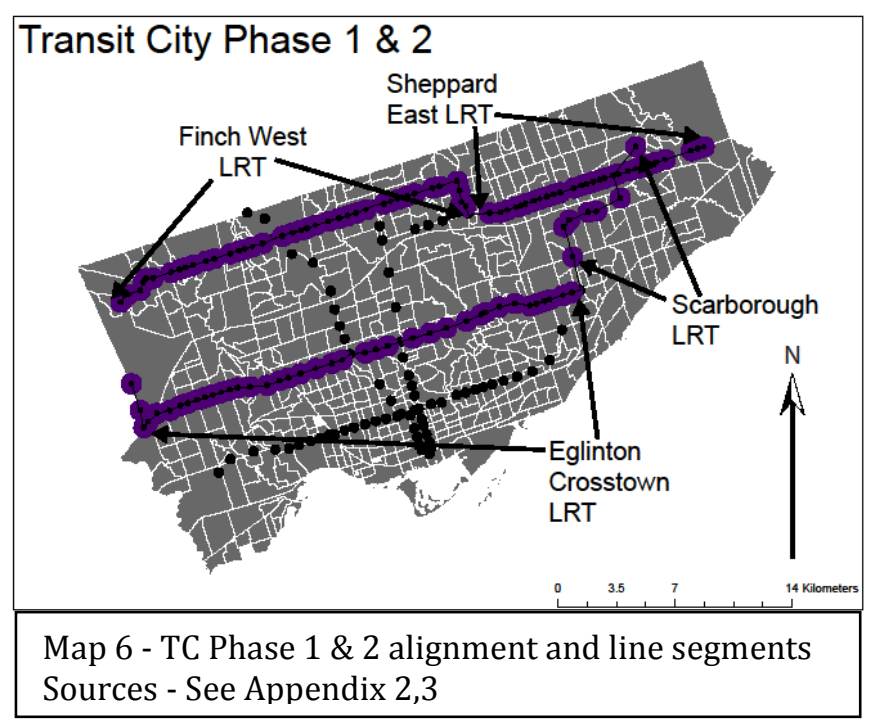

November 13, 2006 he was re-elected and in March of 2007 the TTC officially approved the Transit City Light Rail Plan (Burda \& Haines, 2011b), which included 8 Light Rail Lines (Burda \& Haines, 2011a). ${ }^{18}$ At this point, no funding strategy had been announced. ${ }^{19}$ In November 2007 "The (TTC) Commission approved proceeding with four priority projects: the Eglinton Crosstown LRT, the Finch West LRT, the Sheppard East LRT and the Scarborough RT conversion," (Global News, 2012). Meanwhile, Dalton McGuinty was re-elected on October 10, 2007. The primary issue during this election was faith based schools. However just prior to the election, on June 15th 2007, the Premier announced his intention to provide $\$ 11.5$ billion to public transit infrastructure in the GTA (Kalinowski, 2007). In the spring of 2009 the four LRT projects, along with an extension of the Spadina subway to Vaughan City

\footnotetext{
${ }^{18}$ Running along Sheppard, Finch, Eglinton, Jane, Malvern, the Waterfront and Don Mills, as well as in the Scarborough RT corridor.

${ }^{19}$ This plan in its entirety has yet to receive full funding and remains in the Metrolinx long term strategy; it continues to await the announcement of 'alternative funding mechanisms' (Levy, 2013).
} 
Centre, were selected as the five priority projects in the Big Move Plan and the province finally included the $\$ 11.5$ billion of funding in their budget (Levy, 2013; Global News, 2012; Burda \& Haines, 2011a).

Experts and politicians alike argued that by using LRT technology the plan could serve more residents and low income areas than if subway technology was used, which would reduce congestion significantly and improve low income resident's employment prospects (Burda \& Haines, 2011a; Levy, 2013). In addition it was argued that LRT technology would meet projected demands sufficiently in the proposed corridors for the foreseeable future (Levy, 2013).

However, it seems that politics played a great role in route determination. The fact that the plan brought rapid transit to every councillor's ward accounted for a large portion of its support among City Councillors (English, 2012). English (2012) has noted that the original Transit City plan was announced with virtually no prior technical analysis or public consultation and as such faced many barriers. For example the Scarborough Malvern LRT route is currently adequately serviced by a minor bus route, and the Jane LRT runs along a street that is too narrow to accommodate it (English, 2012). The province's selection process for the Big Move plan was similar, they undertook some studies but for the most part, the projects selected were taken from a list of projects previously requested by municipalities (English, 2012), hence the inclusion of the four prioritized Transit City lines.

In March of $2010 \$ 4$ billion in funding was cancelled as the province attempted to cut costs and reduce their operating deficit amid the great recession (Levy, 2013; Burda \& Haines, 2011b). This led to each of the four projects being reduced in scope significantly for their first 'phase'. The plan was to begin construction, and fund the second 'phase' of construction through alternative funding mechanisms (Levy, 2013). This iteration is listed as 'iteration 3 - Transit City Phase 1' in this study, and was positioned after 'Iteration 2 - Ford Memorandum of Understanding (MOU)' because it was the plan that City council voted to return to after the Ford MOU. 


\section{Iteration 2 - Ford Memorandum of Understanding (MOU)}

The Ford MOU proposed construction of a subway along Sheppard Ave. connecting the Spadina and Yonge lines as well as extending from Don Mills station to Scarborough Town Centre. In this plan, the Eglinton LRT would be completely buried and the Scarborough RT would be converted to an LRT in the old RT right of way. The plan to extend the Spadina line to Vaughan City Centre would remain unchanged.

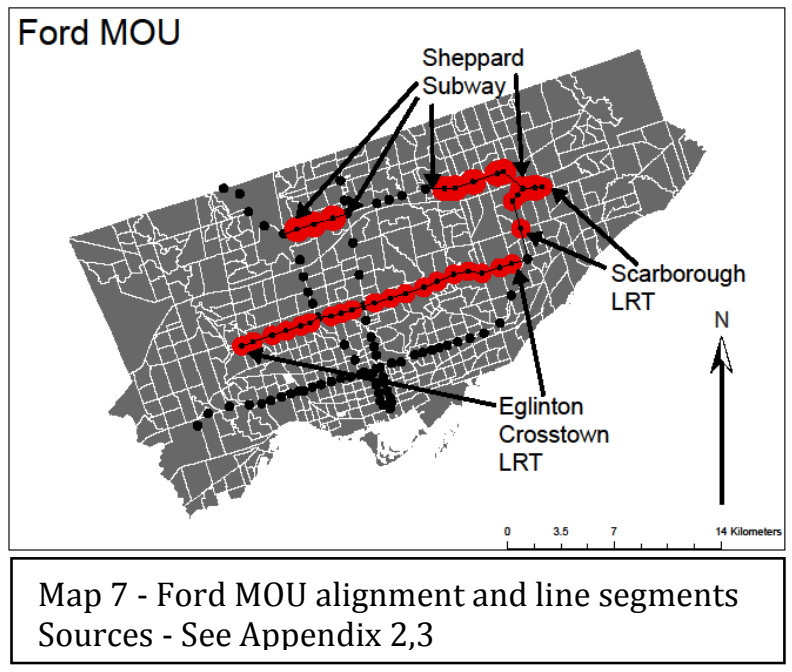

How did this change in direction occur? Mayor Rob Ford replaced Miller as Mayor of the City of Toronto on 1 December, 2010. A large part of his election campaign was focused on changes to Transit City. By the end of the campaign both major candidates, Ford and George Smitherman had promised revisions to the to the Transit City plan, as public opinion about the plan turned negative based on poor perceptions of the St. Clair streetcar exclusive Right of Way, and the idea that LRT was an inferior technology (Bakht, 2013). Ford was elected with a strong mandate and immediately declared that Transit City would not be completed (Burda \& Haines, 2011b; Thompson, 2012). In March 2011 Ford and the McGuinty Provincial government signed a MOU (Burda \& Haines, 2011b; Bakht, 2013). At this time the Liberals were faring poorly in the polls, and were facing an election in the fall of 2011(Burda and Haines, 2012; Warren, 2012). Under this agreement the Province was responsible for funding the Eglinton LRT (whose cost had skyrocketed because it was to be 100 percent buried) and the Scarborough RT (Burda \& Haines, 2011b), while the City of Toronto was responsible for funding the entire Sheppard Subway (Thompson, 2012). Ford hoped to build the subway extension using private funding rather than a property tax increases (Burda \& Haines, 2011b). A private firm would construct the line and be paid back through revenues generated via increased property tax assessments in the area, as well as increased Development Charges (Burda \& Haines, 2011b). Metrolinx accepted the new plan silently (Warren, 2012).

At this point several popular media sources and think tanks put out opinions arguing in favour of Transit City as the plan that provided rapid transit to more people, more low income neighbourhoods, and was fiscally 
responsible (in terms of up front capital costs, and long term operating and capital costs) (Burda \& Haines, 2011b). These same sources sought to dispel the negative images surrounding LRT technology by point out that it runs in exclusive ROWs and as such moves quickly and between stops that are more widely spaced out than streetcars (Burda \& Haines, 2011b).

\section{Iteration 3 - Transit City Phase 1 and ...}

\section{Iteration 4 - Transit City Phase 1 plus Scarborough Subway}

As the December 2010 election faded into the past councillors became more emboldened to defy Ford. Some City councillors argued that the mayor did not have the legal authority to renegotiate the Transit City plan without Council support and Metrolinx sought clarity from City Council on their preferred plans. In February 2012 Council voted 25-18 to reinstate the aboveground version of Eglinton, and the LRT along Finch (Thompson, 2012; Get Toronto Moving, 2014b), while pushing a decision regarding the Sheppard subway into the future (Thompson, 2012). The belief was that creative financing tools, as outlined in the Chong (2012) report, could make the subway along Sheppard a reality. Ford refused to support any of the recommended financing methods, not wanting to increases taxes (Woods, 2012), and as such
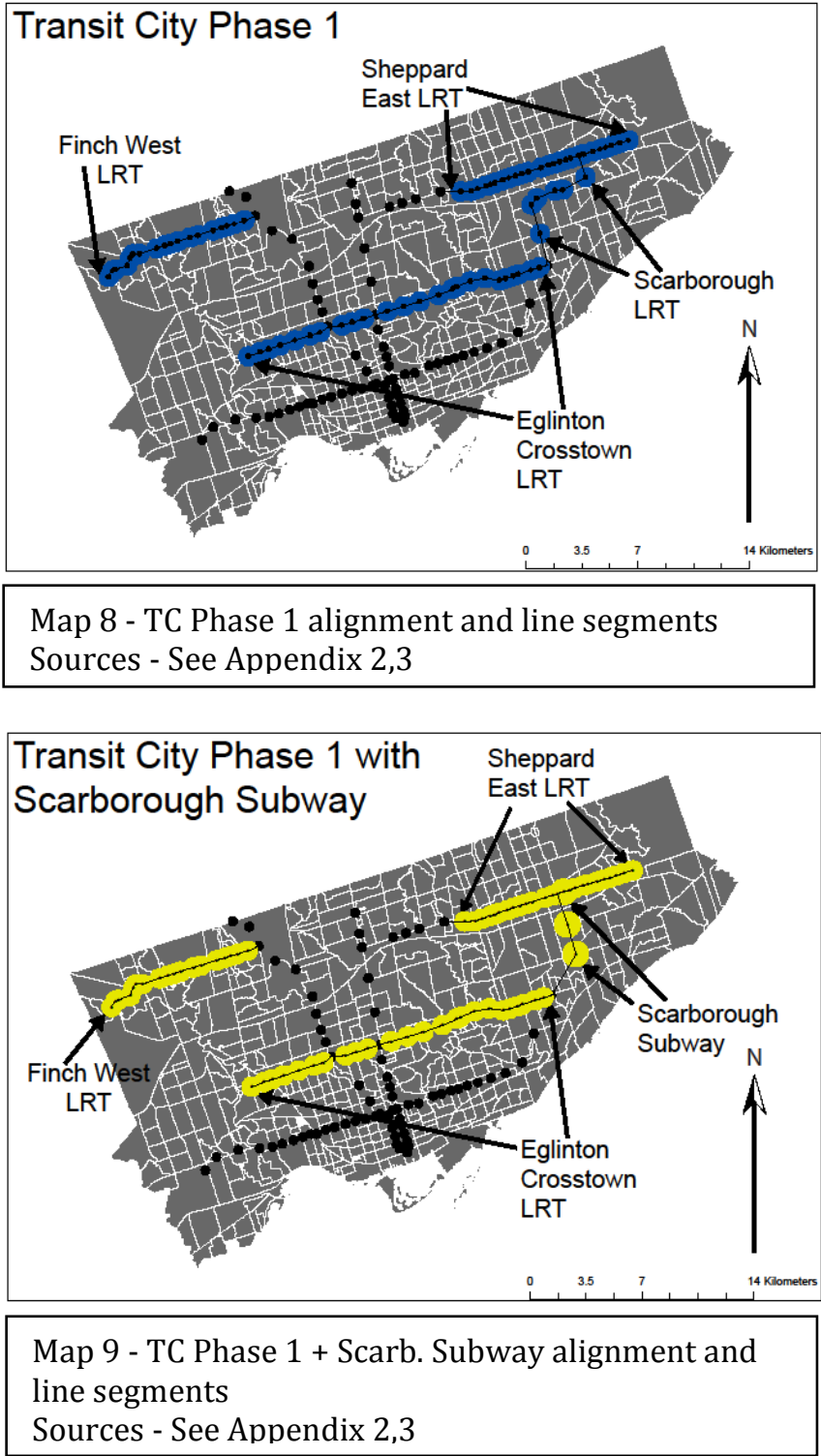

on March 222012 Council voted to build the Sheppard East LRT instead of a subway (Get Toronto Moving, 2014b). As mentioned above, this marked a full return to the 'Phase 1' portions of the Transit City plan. All of this 
was accomplished with little intrusion from Metrolinx or the Province, and with consistent opposition from Mayor Ford, who continues to agitate in support of subway technology.

In the summer of 2013, a provincial by-election was held in Scarborough; during this by-election the Liberal government promised to build a subway rather than an LRT in the RT corridor (Church \& Rogers, 2013). Karen Stintz, the Chair of the TTC, informed Toronto Council that the province would no longer build light rail in Scarborough (Church \& Rogers, 2013), and in response council debated their preferences for the Scarborough corridor and voted 24 to 20 to replace the LRT plan for Scarborough with a three stop subway extension (Hopper, Alcoba \& Bosanac, 2013). ${ }^{20}$ At the same time Council also voted to increase property taxes by 1.6 percent (phased in over 3 years) for 30 years as well as increase Development Charges, in order to fund constructions of the extension (Kalinowski \& Powell, 2013). The province remains committed to providing $\$ 1.48$ billion, which was the amount originally committed to the LRT conversion, the Federal government has agreed provide \$660 million, and the remaining $\$ 1$ billion is to be covered by the City (Kalinowski \& Powell, 2013).

The councillors who voted against the proposal argued that it would result in higher taxes, and debt, as well as that it would reduce transit services in other parts of the city in the long term (as more money would be required to subsidize future riders of the Scarborough subway) (Kalinowski \& Powell, 2013; Kalinowski, 2013). These councillors also argued that subway technology was not a feasible solution for developing transit in the City at large (Kalinowski, 2013).

*For a complete timeline outlining the important dates herein-mentioned see Appendix 4

\footnotetext{
${ }^{20}$ The specific alignment of this subway is still debated as the City desires an alignment running north under McGowan Road while the province prefers for the alignment to remain in the RT corridor. Given the provinces deference to the City's desires up to this point, the City alignment was used in the next section of the study.
} 


\section{Section 6 - Network Efficiency}

This section of the study evaluates whether the changes noted above produced better or worse transportation iterations from a network efficiency perspective. The efficiency of each proposed iteration was assessed based on three aspects of efficiency; (1) accessibility, (2) connection with land use regulations, and (3) connectivity. Several measures were used to quantify each aspect. This is followed by (4) a summary of the relative network efficiency of each iteration.

\section{(1) Accessibility}

\begin{tabular}{|c|c|c|c|c|}
\hline \multicolumn{5}{|c|}{ Accessibility } \\
\hline Iteration & $\begin{array}{c}\text { Total Population } \\
\text { Within Walking } \\
\text { Distance }\end{array}$ & $\begin{array}{c}\text { New Population } \\
\text { Within Walking } \\
\text { Distance }\end{array}$ & $\begin{array}{c}\text { Average } \\
\text { Household } \\
\text { Income of newly } \\
\text { served population }\end{array}$ & $\begin{array}{l}\text { New stations within } \\
\text { walking distance of an } \\
\text { employment district }\end{array}$ \\
\hline \multicolumn{5}{|c|}{ Case 1 - Network 2011 et al. } \\
\hline 1981 Base & 785,306 & - & $\$ 28,338$ & - \\
\hline Network 2011 & $1,230,812$ & 445,506 & $\$ 27,731$ & 25 \\
\hline Let's Move & $1,082,163$ & 296,857 & $\$ 28,564$ & 19 \\
\hline RTEP & 928,399 & 143,093 & $\$ 27,900$ & 7 \\
\hline Conservative Plan & 868,575 & 83,269 & $\$ 34,568$ & 3 \\
\hline \multicolumn{5}{|c|}{ Case 2 - Transit City et al. } \\
\hline 2011 Base & $1,005,942$ & - & $\$ 56,968$ & - \\
\hline $\begin{array}{l}\text { Transit City Phase } \\
1 \& 2\end{array}$ & $1,851,235$ & 845,293 & $\$ 39,658$ & 66 \\
\hline Ford MOU & $1,459,320$ & 453,378 & 44,452 & 24 \\
\hline Transit City Phase 1 & $1,618,062$ & 612,120 & $\$ 38,694$ & 54 \\
\hline $\begin{array}{l}\text { Transit City Phase } 1 \\
+ \text { Scarb. Subway } \\
\end{array}$ & $1,596,367$ & 590,425 & $\$ 39,115$ & 49 \\
\hline Figure 3 - Accessibi & Summary & & & ces - Appendix 2,3,5,6 \\
\hline
\end{tabular}

Figure 3 shows that in the Network 2011 et al. case study, as time went on the proposals became less accessible, began to serve a more wealthy population base, and intersected fewer employment districts. Results from the second case study, Transit City et al. are more positive. Although the original iteration (Transit City Phase $1 \& 2$ ) serves the most people and employment districts, the final two iterations (Transit City Phase 1, and Transit City Phase 1 plus Scarb. subway) are by far superior to the second (Ford MOU) in terms of people and employment 
district served, as well as average household income of the served population. Thus, the worst iteration, the Ford MOU, was eventually rejected in favour of better alternatives.

\begin{tabular}{|l|c|c|c|}
\hline Iteration & Short term Capital Cost & $\begin{array}{c}\text { Cost / new person } \\
\text { within walking } \\
\text { distance }\end{array}$ & $\begin{array}{c}\text { Cost / new station serving an } \\
\text { employment district }\end{array}$ \\
\hline \multicolumn{4}{|c|}{ Case 1 - Network 2011 et al. } \\
\hline Network 2011 & $\$ 2,718,000,000$ & $\$ 6,101$ & $\$ 108,720,000$ \\
\hline Let's Move & $\$ 4,600,000,000$ & $\$ 15,496$ & $\$ 242,105,263$ \\
\hline RTEP & $\$ 1,900,000,000$ & $\$ 13,278$ & $\$ 271,428,571$ \\
\hline Conservative Plan & $\$ 1,000,000,000$ & $\$ 12,009$ & $\$ 333,333,333$ \\
\hline \multicolumn{4}{|c|}{ Case 2 - Transit City et al. } \\
\hline Transit City Phase 1\&2 & $\$ 11,500,000,000$ & $\$ 13,605$ & $\$ 174,242,424$ \\
\hline Ford MOU & $\$ 12,400,000,000$ & $\$ 27,350$ & $\$ 516,666,667$ \\
\hline Transit City Phase 1 & $\$ 8,400,000,000$ & $\$ 13,723$ & $\$ 155,555,556$ \\
\hline $\begin{array}{l}\text { Transit City Phase 1+ } \\
\text { Scarb. Subway }\end{array}$ & $\$ 10,100,000,000$ & $\$ 17,106$ & $\$ 206,122,449$ \\
\hline \hline Figure 4 - Accessibility/Cots Summary & & Sources - Appendix 2,3,5,6,7 \\
\hline
\end{tabular}

Figure 4 shows that when considering cost per new person with access, the results for the second case study (Transit City et al.) remain the same as above; the Transit City Phase 1\&2, Transit City Phase 1, and Transit City Phase $1+$ Scarb. Subway iterations all perform markedly better than the Ford MOU in terms of both costs per new person within walking distance and cost per new station serving an employment district.

However, in the first case study (Network 2011 et al.) there appears to be evidence that the Conservative plan was better than Let's Move plan and the RTEP respectively, since the costs per new person within walking distance is lower in the Conservative plan. However the Conservative plan fares worse in terms of cost per new station serving a major employment concentration as well as in all categories listed in figure 3 (which are absolute in nature), making it a worse proposal on the whole from an accessibility point of view, since it provide less access in an absolute sense. 


\section{(2) Connection with Land Use Regulations}

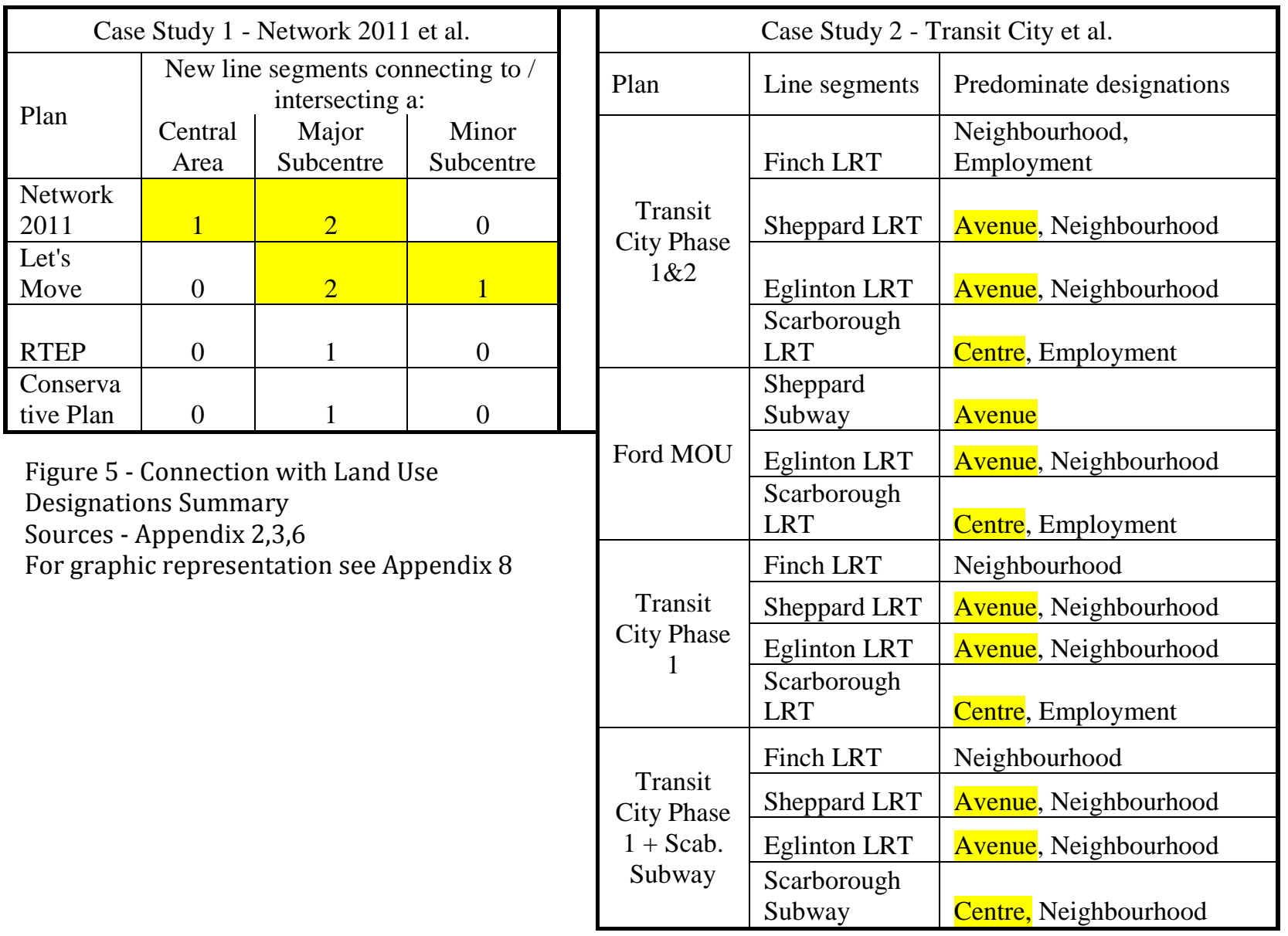

In the first case study (Network 2011 et al.), the Metropolitan Toronto Official Plan - Designated Metropolitan Centres map - outlines a number of major and minor Subcentres as well as the Central area. Land use provisions in these areas (Central Area, Major/Minor Subcentres) were generally transit supportive. They promoted a mix of uses, as well as residential and employment intensification. In addition the major Subcentres designation also promoted pedestrian oriented development. For a more in depth overview of the policies within this plan see appendix 1. In order to understand how well each iteration responded to the land use provisions of the time the number of new line segments connecting to or intersecting the Central Area, or a Major/Minor Subcentres was noted. The results can be seen on the left side of figure 5. As this figure shows, in the Network 2011 et al. case study the Network 2011 iteration connects to the most Central Area and Major Subcentre designated areas. Following iterations get progressively worse as less Central area, Major and Minor Subcentre areas are connected. 

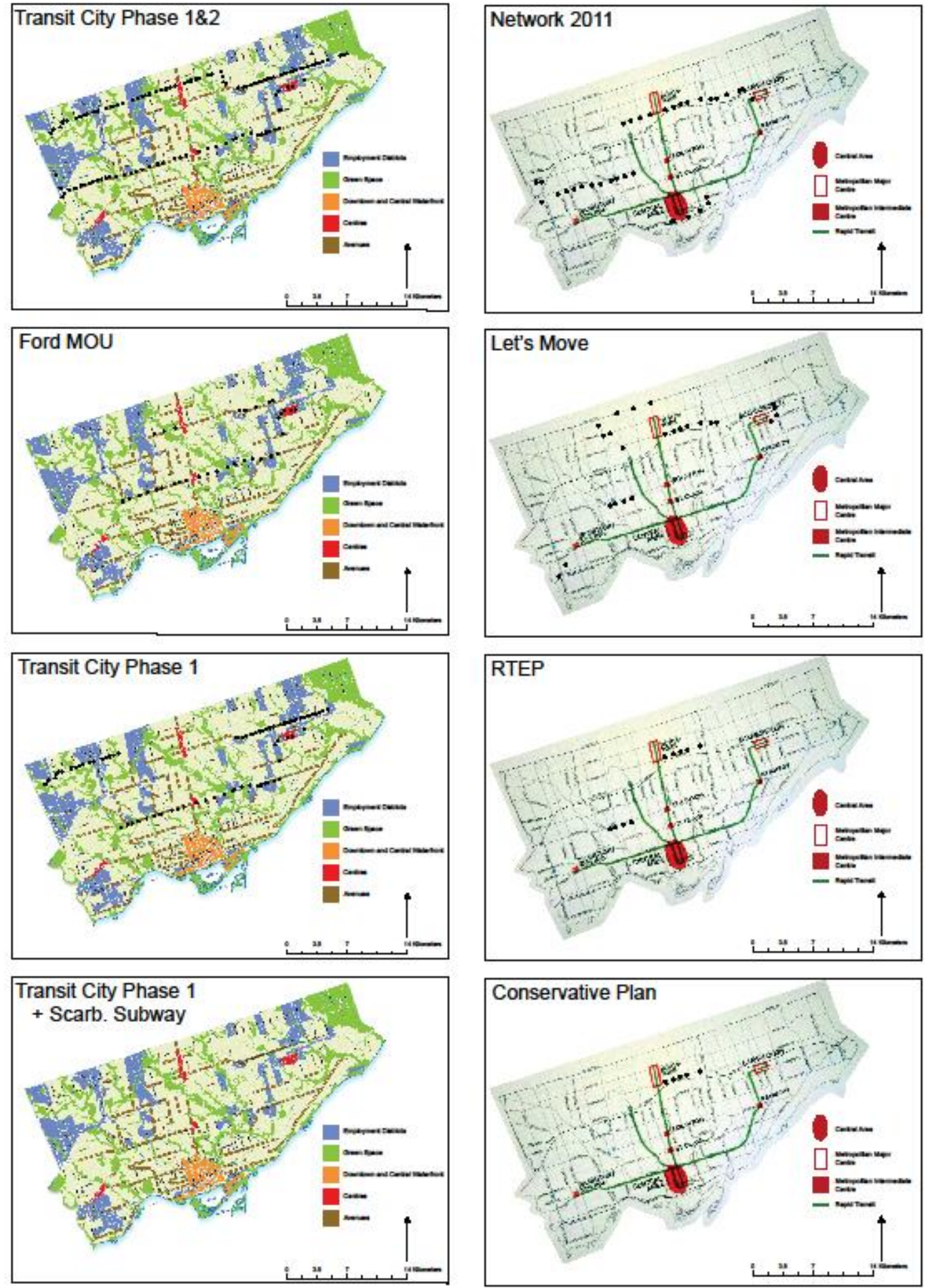

Land use during the

second case study was governed by

Map 10 - Connections with Land Use Designations Sources - Appendix 2,3,

the 2010 Toronto Official Plan. Within this plan the following land use designations are considered transit supportive: Centre and Avenue. They promote a mix of uses, residential and employment intensification, and 
pedestrian oriented development. However, it should be noted that the Avenue designation can be undermined by an underlying neighbourhood designation; which removes permission for significant intensification. On the other hand, employment districts do not promote residential intensification or mixed use development, and neighbourhoods do not promote intensification (except in the form of small scale infill development) or mixed use development (with the exception of permissions for small scale home occupations). For a more in depth overview of the policies within this plan see appendix 1. In order to understand the Transit City et al.'s connection to land use designations the predominate designations found along specific line segments in each iteration were noted on the right side of figure 5. Plans which avoided large stretches of non-transit oriented development were seen as the most efficient from a land use coordination perspective. ${ }^{21}$ In this case study only the Ford MOU iteration avoids neighbourhoods to a significant degree. The worst iteration is Transit City Phase $1+$ Scarborough Subway as it runs along corridors with a great deal more neighbourhood designation than other iteration.

\footnotetext{
${ }^{21}$ It should be noted that in practice, all areas near a transit line do not have to be intensified for the line to be efficient. However, if more areas around a transit stop have the potential to be intensified this increases the likelihood that accessibility will improve in the long term.
} 


\section{(3) Connectivity}

Three measures were used to assess connectivity: The Rho index ( $\rho)$, the Gamma index $(\gamma)$, and the Tau index $(\tau)$. The results of this analysis can be found in the figure 6 .

\begin{tabular}{|c|c|c|c|c|c|c|c|c|c|c|}
\hline \multicolumn{11}{|l|}{ Connectivity } \\
\hline Plan & $\mathrm{Nl}$ & $\begin{array}{l}\mathrm{e} \\
\mathrm{m}\end{array}$ & $\delta$ & $\begin{array}{l}\mathrm{V} \\
\mathrm{t} \\
\mathrm{c}\end{array}$ & $\rho$ index & $\begin{array}{c}\text { Change } \\
\text { from } \\
\text { base }\end{array}$ & $\gamma$ index & $\begin{array}{c}\text { Change } \\
\text { from } \\
\text { base }\end{array}$ & $\tau$ index & $\begin{array}{c}\text { Change } \\
\text { from } \\
\text { base }\end{array}$ \\
\hline \multicolumn{11}{|c|}{ Case 1 - Network 2011 et al. } \\
\hline 1981 base & 3 & 1 & 2 & 4 & 0.75 & - & 0.5 & - & 1.5 & - \\
\hline Network 2011 & 6 & 1 & 2 & 11 & 0.9090 & $18 \%$ & 0.4615 & $-8 \%$ & 3 & $50 \%$ \\
\hline Let's Move & 5 & 1 & 3 & 6 & 0.8333 & $10 \%$ & 0.4583 & $-9 \%$ & 1.6666 & $10 \%$ \\
\hline RTEP & 5 & 1 & 3 & 6 & 0.8333 & $10 \%$ & 0.4333 & $-15 \%$ & 1.6666 & $10 \%$ \\
\hline Conservative Plan & 4 & 1 & 3 & 5 & 0.8 & $6 \%$ & 0.4583 & $-9 \%$ & 1.3333 & $-13 \%$ \\
\hline \multicolumn{11}{|c|}{ Case 2 - Transit City et al. } \\
\hline 2011Base & 4 & 1 & 3 & 5 & 0.8 & - & 0.4583 & - & 1.3333 & - \\
\hline $\begin{array}{l}\text { Transit City Phase } \\
1 \& 2\end{array}$ & 5 & 1 & 2 & 11 & 0.9090 & $12 \%$ & 0.4888 & $6 \%$ & 2.5 & $47 \%$ \\
\hline Ford MOU & 4 & 1 & 2 & 9 & 0.8888 & $10 \%$ & 0.5277 & $13 \%$ & 2 & $33 \%$ \\
\hline Transit City Phase 1 & 6 & 1 & 3 & 10 & 0.9 & $11 \%$ & 0.4761 & $4 \%$ & 2 & $33 \%$ \\
\hline $\begin{array}{l}\text { Transit City Phase } 1 \\
+ \text { Scarb. Subway }\end{array}$ & 6 & 1 & 3 & 10 & 0.9 & $11 \%$ & 0.4761 & $4 \%$ & 2 & $33 \%$ \\
\hline
\end{tabular}

Figure 6 - Connectivity Summary

Sources - Appendix 3

For visual representations see Appendix 9

Figure 6 shows that in the Network 2011 et al. case study, connectivity decreased in all 3 categories over time.

Results from the Transit City et al. case study are less conclusive. The first iteration performed best in the Rho index $(\rho)$ and Tau index $(\tau)$ which were strongly correlated to ridership in studies by Kennedy \& Derrible (2010a). However the difference between each iteration's Rho index ( $\rho$ ) was minimal, owing to minimal differences in the maximum number of transfer possibilities (Vtc) and no differences in the number of multiple edges (em). The Tau index $(\tau)$ of the first iteration was significantly higher than that of the following iterations due to the 
combination of a high number of lines and a low number of maximum transfers. With regards to the Gamma index $(\gamma)$ the Ford MOU, which fared worse in the Rho index, performed the best.

The reason for the difference is simple. The Gamma index measures the connectivity of a network compared to how connected it could be, and as such a proposal which primarily improves connectivity of existing nodes will perform best; whereas the Rho index $(\rho)$ and Tau index $(\tau)$ assess connectivity with emphasis put on the need to transfer (lower is better) and ability to transfer (high is better). Given this, the difference in results becomes clear. The Transit City iterations sought to create new lines and nodes and integrate them into the existing system, thereby creating more lines and transfer possibilities. On the other hand, the Ford MOU sought to create additional links between existing nodes in the form of the Sheppard subway. Academics such as Levy (2013) term the approach used in the Ford MOU essential redundancy, which provides additional routes between different nodes. This type of redundancy is essential in well developed public transit networks in order to allow riders to have a greater variety of choices; allowing them to bypass delays (Kennedy, \& Derrible, 2010a). However, as mentioned in Levy (2013), the GTA transit system lacks this type of redundancy in the downtown, ${ }^{22}$ not in the inner suburbs. Since the Rho $(\rho)$ and Tau $(\tau)$ indexes are strongly correlated to increased ridership (Kennedy \& Derrible, 2010a), and since the Ford MOU produces essential redundancies in a less than ideal place, it would appear that from a connectivity perspective the first Transit City iteration performs the best with the third and fourth performing only slightly better than the Ford MOU.

\footnotetext{
${ }^{22}$ To alleviate congestion at the transfer points between the Yonge/University/Spadina and the Bloor/Danforth lines.
} 


\section{(4) Efficiency summary}

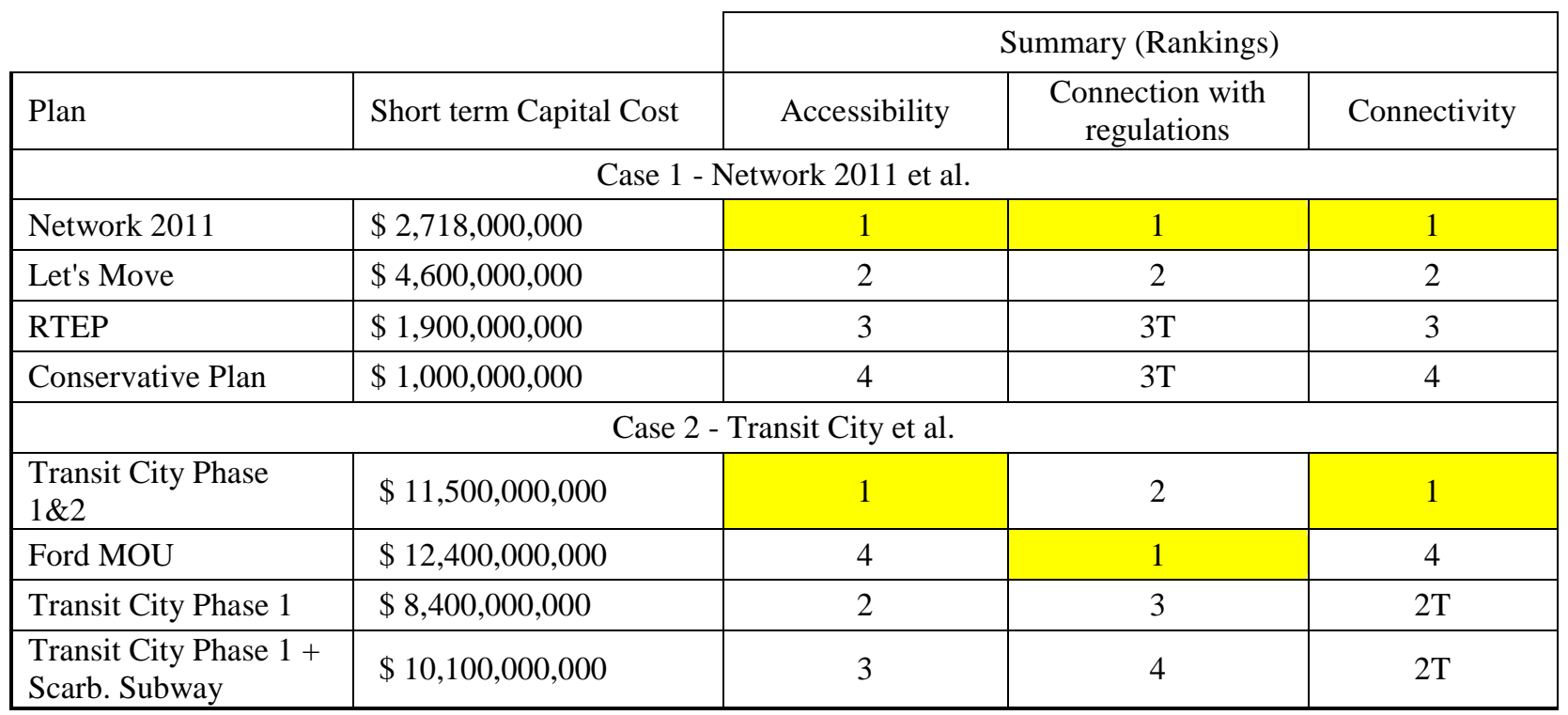

Figure 7 - Efficiency Summary

Sources - Appendix 7

For visual representations see Appendix 9

With regards to the Network 2011 et al. case study, it would appear that the first iteration is by far the most efficient from all three perspectives and that the iterations which follow are progressively and uniformly worse in terms of accessibility, connection with land use regulations, and connectivity. With the exception of the second proposal, costs decreases in line with efficiency.

With regards to the Transit City et al. case study, the second iteration (Ford MOU) performs the worst of the four iterations from an accessibility and connectivity perspective, and costs the most. However, it does perform best in terms in connection with land use regulations. However its performance in this category does not outweigh its poor performance in the others, especially given the fact that (a) connection with land use will only improve the performance of a network if development occurs, and (b) that land use regulations are relatively easy to change (in comparison to the location of population, low income populations, and employment districts). Therefore, the Ford MOU is by far the worst of the iterations in this case study. The Transit City Phase $1 \& 2$ (1st) and Transit City phase 1 (3rd) iterations are superior to the Transit City Phase $1+$ Scarb. Subway (4th) iteration in every category. Consequentially, the two most efficient iterations are the Transit City Phase 1\&2 (1st) and the Transit City Phase (3rd) iterations. This is because, although the first iteration outperforms the third, it also costs significantly more. 
For that reason the first and third iterations are both good solutions given different financial restrictions. Ideally, both would be accompanied by changes to land use regulations along their routes in favour of the Avenue designation (with an underlying Mixed Use designation). 


\section{Section 7 - Transit Governance That Works}

As previously discussed, there is no one size fits all solution for governance; governance solutions must be specific to the regions they are in because of the importance of context and place (Bird \& Slack, 2007; Hambleton \& Gross, 2007). The previous sections studied the two most recent large scale public transit infrastructure cases, following the evolution of each case, and noting the relative efficiencies of each iteration within the case. This section seeks to draw connections between the efficiency of different outcomes and the governance structures that produced them, in order to understand the characteristics of governance structures that produced good and bad decisions in the GTA context. In essence it aims to identify the characteristic of transit governance that works in the GTA context.

The section is organized as follows. As mentioned in the literature review, the characteristics of transportation governance were subdivided into the following three categories: Authority, Legitimacy/accountability, and funding/financial capacity. This section was also subdivided using these categories. For each category, a brief description of governance in Toronto was given; with supporting data drawn from the historical review. Following this description is an analysis of how the specific characteristic produced positive and negative results from an efficiency perspective.

Authority

Authority can differ in many ways as noted in the literature review section. The case studies were evaluated in terms of the dispersal of authority between governments and dispersal of authority within governments. In addition, continuity in authority and the use of authority was commented upon.

During both the case studies authority was evenly dispersed between governments. This means that both the province and the respective municipal government (being Metropolitan Toronto or the City of Toronto) had relatively equal decision making power. This is because the provincial government could not proceed in either case without the agreement from the municipal level. This being said, authority was slightly more dispersed between governments in the Network 2011 et al. case study. This is because there were two separate levels of municipal government present in this case study, the upper tier Metropolitan Toronto Council, and several lower tier Borough Councils. It is also important to note that during both case studies there were influential ABCs (Agencies Boards and 
Commissions) which exercised authority during the initial planning stages; these being the TTC in the first case study, and the TTC and Metrolinx in the second case study.

In terms of internal authority, at the municipal level, authority was more centralized in the Transit City et al. case study. This is because there were two tiers of municipal government during the Network 2011 et al. case study. This two tier government system tended to promote local voting blocks, which produced division within Metro Council, decreasing the decision making ability of that body (Sancton, 2005). This was especially evident in the debates surrounding the Network 2011 iteration. On the other hand, during the Transit City et al. case, the City of Toronto was the only active municipal government, and was generally unified, first in deference to Mayor Ford, and later in opposition to him.

In both cases, internal authority at the level of the Provincial Government was more concentrated in the hands of the Premier than was true of either the Chairman of Metro Toronto or the Mayor of the City of Toronto. Both the Metro Chairman and the Mayor of Toronto represented one vote among many, and had to seek to build consensus and support in their respective councils. On the other hand, power in the Canadian parliamentary system is concentrated in the cabinet, and more specifically with the Premier, due to party discipline and the party system; the Premier's power of appointment and dismissal (to/from cabinet and ABCs); executive federalism; and the concentration of technical resources in the executive branch (Savoie, 2009; Savoie, 2006; Simpson, 2001; Savoie, 1999).

The different natures of City Council and the Ontario Parliament also produce differences in the likelihood of continuity of those holding authority over time. There is a very high turnover rate among municipal councillors. At the Provincial level, turnover of individual MPPs is not important; what is important is turnover in the ruling party, since it is party leaders who tend to make important decisions about large budget allocations. Thus, in order for there to be continuity of authority at the municipal level many councillors would need to be re-elected, whereas in the provincial context only the party need be re-elected. As a result it is more likely that continuity will exist at the Provincial level. That being said, continuity of those in authority differed markedly between the two case studies. The Network 2011 case saw provincial leadership held by (1) a Liberal led coalition government with the NDP (1985-87), (2) a majority Liberal government (1987-90), (3) a majority NDP government (1990-1995), and (4) 
a majority Progressive Conservative government (1995-2003). On the other hand, the Liberal party has been in power for the entirety of the Transit City Case Study (2003-2011, majority; 2011-present, minority).

A common theme also emerged in terms of the use of authority. It seems that plans were altered significantly, or funding announced, either prior to or after major elections. In fact only the Network 2011 iteration came about without the impetus of a coming or past election.

\section{Authority - Positive Results}

1) ABCs a Positive Influence When Setting Priorities - In both case studies, the use of authority by ABCs in setting the agenda was positive; likely because $\mathrm{ABCs}$ make decisions based on technical analysis rather than for political reasons. In the Network 2011 et al. case study the TTC prepared several reports, which culminated in the Network 2011 plan. The Network 2011 plan was by far the most efficient of all the iterations in the Network 2011 et al. case study. Likewise, in the Transit City et al. case study, although Mayor Miller created the original Transit City Plan, the TTC prioritized the four lines which would go forward, a decision which was later supported by Metrolinx. ${ }^{23}$ The lines which were chosen excluded some of the more questionable/problematic lines; the Scarborough-Malvern, and Jane LRTs.

If $\mathrm{ABCs}$ make the best decisions from an efficiency perspective then why not then let them make decisions with regards to transit infrastructure planning? While plans can be studied and there technical efficiency noted by experts, the reality is that these lines represent a large public expense, paid for by members of the public. As such the determination of how that money is spent should be made by politicians who are elected representatives. In addition, since these allocations are necessarily geographic, they favour some more than others and are particularly vulnerable to be viewed as expressions of favouritism. As such, they must find approval in the public eye through democratically elected politicians.

2) Continuity at the Provincial Level - Transit infrastructure projects have long implementation timelines and as such continuity in authority at the provincial level has prove to be essential. In each case study the original iterations performed best from an efficiency perspective (the role of $\mathrm{ABCs}$ in determining these iterations was seen as one

\footnotetext{
${ }^{23}$ It should be noted that at the time of this decision there was some political representation on the board of Metrolinx.
} 
reason for this). However, in the Network 2011 et al. case study, the lack of continuity in the ruling provincial government meant that the original iteration changed significantly over time, with each new provincial government announcing a new iteration; which was less efficient that the iteration which preceded it. As noted by Levy, incoming governments were prone to trimming or cancelling large infrastructure projects by declaring them "wastes of money," or "fiscally out of reach," (Levy, 2013, 163). The Network 2011 et al. case study is ripe with examples of lines being cancelled or shortened, and every time this occurred efficiency of the network decreased. For example, the shortening of the Sheppard subway line in Let's Move and subsequent iterations is part of the reason why the line continues to experience low ridership and requires large subsidies even today (Levy, 2013). Its shortening also meant that it no longer accomplished one of its primary land use goals, connecting the Scarborough and North York City Centres.

On the other hand, in the Transit City et al. case study, continuity at the provincial level meant that the provincial government made very few changes to the original plan over time. In addition, continuity at the provincial level allowed City Council the opportunity to return to the original plan in iteration 3 - Transit City Phase 1 after the Ford MOU was found to be inadequate. In this vein, Metrolinx provides a limited degree of further policy continuity at the provincial level; since, as an expert led board, it will remain in a position to argue for continuance of existing plans even if the provincial government does change.

\section{Authority - Negative Results}

1) Coordination with Land Use Harmed by Fragmented Decision Making - In the first case study (Network 2011 et al.) coordination with land use consistently declines over time. This likely occurred because Metro Council was responsible for land use planning whereas a majority of the decisions with regards to transit infrastructure provision in subsequent iterations were made by the province. Further support for this argument can be found in the Transit City et al. case study, where a City decision, to move towards the Ford MOU, seems to align better with existing City policy regarding land use; although it should be noted that this was not explicitly mentioned as a reason for the change. Additionally, it should be noted that the four Transit City lines were also selected by the City of Toronto, and for the most part run along Avenues designated for higher order development, with dispersed sections of Neighbourhood designations. 


\section{Accountability/legitimacy}

Both municipalities and the Province, in both case studies, have legitimate authority in the decision making process. It is therefore important to understand who they are/were accountable to in each case, and understand what incentives this provides.

In both cases local politicians were accountable to a smaller segment of the regional population than provincial politicians. In the Network 2011 et al. case study this division was further exasperated as lower tier borough politicians were only responsible for very small geographic areas. With regards to transit infrastructure, this provides certain incentives for each politician, assuming one of their goals is to represent the wishes of their constituents. The smaller geographic bounds of local politicians' incentivizes those politicians to think locally when considering a rapid transit expansion plan; ie. will my ward benefit from this project. This type of behaviour was clearly a factor in the City Council debates surrounding both case studies.

The incentives are usually quite different at the provincial level. Generally speaking, provincial parties are concerned about re-election province wide rather than in a specific riding. This means that they are concerned about the affect of their policies in the entire region they affect, and how these policies will affect other regions as well. For example, in the lead up to the 2007 election, the Liberal government announced new spending for transit in the GTA rather than only in Toronto, and then appointed a RSPB, Metrolinx, to prioritize the projects within the region that would work best from an efficiency perspective. The case of the 'Transit City phase 1 plus Scarborough Subway' iteration is an exception that proves the rule. In this case, a by-election in an individual riding in Scarborough was held, and the Provincial government made a promise to the people of that specific riding, and supported the less efficient subway option; whereas they had previously supported the LRT proposal.

In addition to different incentives being provided from different constituent bases, there is also a difference between the relative importance of these issues to constituents at the two levels of government. Politically, the location of new public transit infrastructure affects a councillor or mayor to a greater extent than it does the governing provincial party. As such, municipal politicians have a further incentive to choose a political line rather than an efficient line in comparison to a provincial politician. A provincial party on the other hand, has a political motivation to choose a plan that will benefit the region, since constituencies are much larger at this level. 


\section{Accountability/legitimacy - Positive Results}

1) Creation of a Regional Spatial Imaginary - In the Network 2011 et al. case study local politicians aggressively defended the interests of their local constituents. For example, they delayed approval of the Network 2011 iteration due to infighting regarding the phasing and prioritizing of projects; which eventually led the provincial Liberals reconsidering that proposal and instead proposing the less efficient Let's Move iteration. Specifically it led to the shortening of the Eglinton and Sheppard subways so that all parties could be appeased. This infighting between and within governments was destructive to the final goal of regional integration and system building.

The creation of Metrolinx in the second case study (Transit City et al.) is viewed as a positive step towards ending this process of polarization. As noted by Horak, (2008), Boudreau, et al. (2006), the OECD (2009), when policy power is fragmented, cooperation between actors becomes the key challenge. Horak (2008), notes that the more coordinated different actors' original agendas are, the more likely they are to come to cooperate. How can the policy agendas of many municipal actors, with divergent interests, be brought in line with one another, how did Metrolinx help with this?

Regions are constructed as political spaces, rather than naturally existing in the minds of citizens (Boudreau, 2007). Addie (2010) recognizes that creating regional institutions shapes political discourse. Therefore, by creating a regional governance body, Metrolinx, the Province has encouraged GTA residents to think about transit issues on a regional scale, and in doing so has legitimized actions which support regional transit integration. This in turn can help with the convergence of municipal politicians' agendas, since it encourages constituents to think about transit issues on a regional basis rather than locally. There is some evidence of this occurring in the second case study. City of Toronto Council's support for the switch from the less efficient iteration 2 (the Ford MOU) to iteration 3 (Transit City Phase 1) was to a degree based on iteration 3's ability to serve more Toronto residents at a lower cost. This rationale considers regional rather than local benefits whereas the rationale supporting the Ford MOU was focused on local benefits; specifically to a subsection of residents in Scarborough and North York, who felt they deserved a subway rather than inferior LRT technology.

This begs a further question; will a regional perspective always produce more efficient result, could this perspective not be used as a means to legitimize decisions which are less efficient? While this is a possibility, a regional spatial 
imaginary provides residents with a decision making matrix that considers the transit network as a regional system. This will incentivize councillors to thinks along these same lines. As previously mentioned, academics have found that transit functions regionally and as such, it is likely that decisions made with regional interests being considered will generally be more efficient.

\section{Accountability/legitimacy - Negative Results}

1) Decentralized Decision Making - Decisions regarding the allocation of public funds must be approved by legitimate political actors. As noted in the authority section, decision making in the case studies was decentralized as both the province and the relevant the municipality had a say in the final plan. This created negative result because these two governments have two different political incentives creating policy divergence, and therefore slowing the process of infrastructure provision. In addition, because municipal desires tend to be more localized, incorporating these into the iterations made each iteration less efficient.

When local politicians put their own priorities before regional priorities this creates inherent competition between different players within a municipality and between levels of government, which in turn frames the transit conversation as a zero sum game; fueling political polarization, and decreasing the legitimacy of regional action in the minds of citizens. For example infighting between factions on Metro Council representing different lower tier Cities, regarding the Network 2011 iteration, gave the Provincial government pause; this eventually led the provincial government to suggest the vastly inferior Let's Move iteration. Infighting in City of Toronto Council during the Transit City et al. case study discredited the largely superior Transit City phase 1 and 2 iteration, which made the province reluctant fight for these plans when Mayor Ford asked to have them altered, ultimately leading to the vastly inferior Ford MOU.

\section{Funding/Financial capacity}

There was a significant difference in the funding arrangements between the two cases studies, but very little difference in the relative financial capacity of the two levels of government.

The major difference between the two case studies is that in the Network 2011 et al. case study the Province was responsible for funding 75 percent of capital expansion programs, and the municipality the other 25 
percent (Levy, 2013). ${ }^{24}$ This meant that Metro Toronto had 'skin in the game' (a term commonly used by academics to denote that a municipal government has contributed to part of the capital costs of a project). This produced an incentive for municipal politicians to be more involved in the decision making process. On the other hand, in the Transit City et al. case the City of Toronto originally had no 'skin in the game' as all of the money for the plan was provided by the province. In this case, the City of Toronto put its 'skin in the game' by choice, when it wanted extras that were not part of the provincial plan; such as the Scarborough subway in iteration 4, and the Sheppard subway in iteration 2. With no 'skin in the game' there is less incentive for the municipalities to get involved in selecting the location of new infrastructure; especially because they may raise expectations and be asked to pay for the 'extras' which they lobby for (such as the Sheppard and Scarborough subways).

There are several similarities between the case studies when it comes to financial capacity. The Province has traditionally funded transportation infrastructure through one off grants from general revenue (Levy, 2013). These grants have been the driving force behind many of the transit infrastructure projects in the GTHA. ${ }^{25}$ In both cases the municipalities were limited to two main own source revenue tools (the property tax and user fees) which are insufficient to pay for major transit upgrades alone (Golden \& Knowles, 2012; Kitchen, 2008). Another similarity is that in both case studies, when a subway was suggested on Sheppard, it was proposed that the subway be built by a private company, who would be reimbursed through increases in property taxes created by increased property values around the new line (see Coopers \& Lybrand, \& IBI group, 1991; Chong, 2012). This strategy has never been implemented. In both cases innovative funding models were considered, and ultimately rejected, by municipal politicians.

\section{Funding/Financial capacity - Negative Results}

1) Reliance on General Revenue (Funding Sources) - When general revenue is the main source of funding for a project, transit infrastructure is forced to compete with other government responsibilities and expenditures. Political

\footnotetext{
${ }^{24}$ A second, minor, difference between the two case studies, was the involvement of the Federal government in the Transit City et al. case study, whereas they were not involved in the Network 2011 et al case. Federal involvement helped secure a small amount of additional money for the Scarborough RT conversion, the Sheppard LRT, and the Spadina Subway extension (Levy, 2013).

${ }^{25}$ Although outside of the scope of this study, it should be noted that the Province has announced a significant change in funding framework going forward; the remaining \$34 Billion of the Big Move plan is to be funded by new revenue generating tools collected in the GTHA and earmarked specifically for spending on transportation infrastructure (Metrolinx, 2013). No decision has been made with regards to selection or implementation.
} 
spending from general revenue is driven by the short term nature of the election cycle and the rapidity of economic change in a globalized economy (Hambleton \& Gross, 2007). On the other hand, transportation planning requires a long term approach, and is tied to urban form and population; which does not change as quickly as economic conditions. This has led to three negative outcomes.

Firstly, transportation infrastructure is at a distinct disadvantage in this competition for funds in comparison to more universally supported policy goals, especially when there is a lack of continuity at the Provincial level. ${ }^{26}$ For example, a recession in the early 1990s led to Federal cuts in block grants to the provinces. The fiscally-conservative economic culture of the time, combined with this reduction in transfer payments, led to a massive reduction in transit infrastructure spending (Levy, 2013). This was done in order to maintain more universally supported policy goals such as quality healthcare and education (Addie, 2010; Soberman, 2006). This incident caused the shift from the RTEP to the less efficient Conservative Plan in the Network 2011 et al. case study.

Secondly, the short term nature of the election cycles, and rapidly changing economic conditions has led to short term and ever changing government priorities. This has resulted in unstable funding over time for transit infrastructure. Unstable funding has led to funding primarily for projects within a plan, rather than a compete plan (Soberman, 2006). This is most evident in the Network 2011 et al. case study, where line segments were kept as funding was removed over time, but the line segments no longer worked to create the intended network. Generally this is evidenced by the almost uniform decrease in all measures of connectivity in the Network 2011 et al. case study over time. Specifically it can be noted that several key goals of the original iteration were never realized. For example, a key goal of the Network 2011 iteration was relieving congestion at Bloor-Yonge station, an issue which was left unresolved after the removal of the DRL (part of Network 2011) and the Spadina Loop (part of Let's Move). Another key goal was to connect the Major and Minor Subcentres via rapid transit. However, shortening the Sheppard line meant that Scarborough and North York Town Centre were never connected. Again more broadly this led to a reduction in the Network 2011 et al. case study's connection with land use regulations. In the Network 2011 et al. case study, as lines were shortened they connected and intersected with less and less transit supportive areas. There is also evidence that unstable funding negatively affected the Transit City et al. case. The great recession and

\footnotetext{
${ }^{26}$ Since as mentioned above, politicians tend to regard the transit plans of other governments as "wastes of money," or "fiscally out of reach," (Levy, 2013, 163).
} 
a large government deficit resulted in the move from the Transit City Phase $1 \& 2$ iteration to the less efficient Transit City Phase 1 iteration.

2) Forcing Municipalities to have 'Skin in the Game' - Because municipalities have less financial resources, there financial capacity is less, and forcing them to have 'skin in the game' could lead to the dilution of projects. For example the RTEP iteration was significantly reduced by Metro, who did not want to cover its share of the costs.

The case studies have also show that when municipalities had 'skin in the game' they had a further, fiscal, incentive to become involved in the selection of the lines within a proposed plan. As noted in the legitimacy/accountability section, because municipal politicians are accountable to their local constituents, who make up a very small geographic area, they are incentivized to make decisions which consider local rather than regional benefits. The above section demonstrated that this incentive has resulted in less efficient decisions from a transit infrastructure perspective. The example given is the intense involvement of local politicians in the Network 2011 et al. case study, whose fragmentation delayed the provincial response to the Network 2011 iteration, and eventually diluted the contents of the RTEP.

On the other hand, in the second case study, the City of Toronto originally had no 'skin in the game'. They chose to put 'skin in the game' in order to secure a subway along Sheppard first, and later along Scarborough, both less efficient decisions than the previous iterations, supporting the notion that municipalities generally supported less efficient iterations. Eventually 'skin in the game by choice' led city council to abandon the expensive Sheppard subway and return to a more efficient proposal, and it seems this argument is beginning anew, with two mayoral candidates recently noting that they would like to see the Scarborough subway decision revisited because it is not fiscally responsible (Armstrong, 2014).

In addition, if local money is required to build projects, it is unlikely that these projects will be regional in nature. In fact municipalities are incentives to think in the exact opposite way. The scale at which revenue is collected by local actors is too small to deal with externalities. Currently, GTA transit agencies collect (a) fares for rides within their jurisdictions and (b) subsidies from municipalities (who rely primarily on property taxes collected within their municipal boundaries). As a result there is no incentive for these actors to expand transit outside of their boundaries and provide efficient connections. This is because if they did so they would be creating positive externalities, by 
subsidizing riders from outside of their city, who do not contribute to the transit agency through municipal property taxes. Is it any wonder then that the TTCs Network 2011 iteration failed to reach regional boundaries in most instances, and as such was determined to lack regional qualities by the province? Or that that City of Toronto only offered to put 'skin in the game' for project which did not reach regional boundaries? 


\section{Section 8 - Recommendations}

What has been learned about the characteristics of good and bad governance of large scale transit infrastructure in the GTA? What characteristics have produced or facilitated positive results from an efficiency perspective, which have produced negative results?

The case studies have shown that expert led ABCs as priority setters help to produce efficient plans from the outset. What is needed then is for these plans to be supported in the long run. The cases have shown that there are two important ways for this to be accomplished. Firstly continuity of key decision makers is required to ensure that financial and political support is constant. The case studies have shown that continuity in authority is more likely at the provincial level and that municipal politicians have perverse incentives to support political rather than technically sound plans. As noted by Slack "According to the "Subsidiarity principle" (Barnett, 1997)... expenditure responsibilities should only be assigned to a higher level of government if it can be demonstrated that it can carry out the function more efficiently than the lower level," $(2009,26)$. In this case it has been sufficiently proven that based on the incentives for municipalities and councillors to think and act locally rather than regionally, and considering the fact that transportation must function in a regional context, it is more appropriate for transportation authority to be concentrated at a regional level. Secondly, plans must be legitimize in the eyes of the public through the democratic process, and the case studies demonstrate that regional institutions can help to create a regional spatial imaginary, which in turn can help legitimatize regional plans and make residents think regionally. It is important to remember that this report is suggesting that the province is the ideal place for the majority to authority to rest, or that that the current arrangement (Metrolinx as a RSPB), is ideal in terms of creating a regional spatial imaginary; but rather that in the GTA it is important that a regional spatial imaginary be created, that governance of large scale public transit infrastructure have a great deal of continuity, in a body with proper incentives, that expert influence in the formative phase is essential, and that decisions must be legitimized through public institutions.

On the other hand, what characteristics have produced or facilitated negative results from an efficiency perspective? What characteristics should be avoided going forward? The case studies have shown that a funding framework dominated by general revenue results in unstable transit funding, which provides more opportunities for plans to be reduced. This has had detrimental impacts to the network building potential, and therefore efficiency of new infrastructure. In addition, the case studies have shown that the decentralized decision making framework, 
which gives significant power to municipalities, decreases the likelihood that plans will be carried out as originally intended and gives a degree of power to municipal politicians who have an incentive to change plans to help them locally rather than think regionally. This is also the reason why forcing municipalities to put 'skin in the game' is also seen as a negative. Again this section does not suggest that municipalities be excluded from decisions regarding transit infrastructure. In fact the last finding, that the province has dealt poorly with coordinating transit with land use suggests the opposite do some degree. However what this conclusion does suggest is that in the current governance framework, municipal politicians are faced with incentives which promote local rather than regional goals, which has slowed the process of infrastructure provision.

Considering that the province has final authority over transportation governance in the constitution, and given these findings, the following are a series of recommendations for the Province in regards to the governance of large scale transportation infrastructure planning going forward:

1. Change is needed. There is significant room for improvement.

- The two case studies clearly show that decisions made with regards to large scale public transit infrastructure provision have not been ideal; they have led to less efficient iterations of each original plan.

- Governance structures did not changed substantially between the two case studies. The fact that more positive results were noted in the second case study is largely the result of little government turnover at the provincial level, rather than improved governance.

2. The province should further delineate the responsibilities of different political actors in the governance of transportation infrastructure. How power should be shared will require further study and public review but should give consideration to the following:

a. When delineating responsibilities, the province should seek to centralize decision making authority. This will help ensure that infrastructure can be delivered, rather than debated.

- Decentralized/split authority, between municipalities and the province, has led to infighting. This has in turn slowed the provision of infrastructure.

b. When delineating responsibilities, the province should seek to increase continuity of key decision makers.

- The case studies have demonstrated that continuity at the provincial level helped produce more efficient results from an efficiency perspective.

- Further study and public review is needed in order to determine how continuity can be improved while still allowing for responsible government. 
3. In any new governance structure, the province should ensure that transit infrastructure plans are first formulated by staff through professional, empirical studies; and then approved by politicians, not vice versa. This should include new iterations of existing plans.

- The case studies have demonstrated that expert led decision making is essential during the policy formulation stage; generating the most efficient plans.

4. Notwithstanding the efficiency of expert led decision making noted above, the provincial government must ensure that politicians continue to have the final say with regards to the approval of plans, since these plans represent an allocation of public resources. How this can be best achieved in a GTA context, while simultaneously centralizing authority and improving continuity, will require further study and public review, but should give consideration to the following:

a. The province must ensure that decision makers are faced with incentives that encourage them to make choices based on the regional effects of a plan.

- The case studies have shown that the geographically small constituencies of municipal politicians provide these politicians with incentives to act locally rather than thinking regionally. This has in turn produced poor results.

b. The provincial government should continue to work towards creating a regional spatial imaginary.

- A regional spatial imaginary can help legitimize, and create an appetite for, action on a regional scale.

- A regional special purpose body, with functional boundaries that match the service being provided, can help in the creation of a regional spatial imaginary. This body could be a continuation of Metrolinx, which is an already established regional special purpose body which functions at an appropriate scale.

5. When considering what revenue streams will be used to fund large scale transit infrastructure going forward, the province should ensure that funds from general revenue are not heavily relied upon.

- Spending from general revenue is driven by the short term nature of the election cycle and the rapidity of economic change in a globalized economy (Hambleton \& Gross, 2007), while transportation planning requires a long term approach, and is tied to urban form and population; which do not change as quickly as economic conditions.

6. The provincial government should ensure that any new governance structure supports the coordination of land use provisions and transit infrastructure plans.

- This will involve adjusting both Official Plans and the content of Transit plans, and can be achieved in multiple ways depending on where authority for these types of decisions eventually lies. 


\section{Section 9 - Appendices}

Appendix 1 - Summary of analysis of land use regulations

\begin{tabular}{|c|c|c|c|c|c|}
\hline \multicolumn{6}{|c|}{ Land Use Planning Designations } \\
\hline Designations & $\begin{array}{l}\text { Types of uses } \\
\text { promoted? }\end{array}$ & $\begin{array}{l}\text { Promotes } \\
\text { increased } \\
\text { Residential } \\
\text { density? } \\
\end{array}$ & $\begin{array}{l}\text { Promotes increased } \\
\text { Employment } \\
\text { density? }\end{array}$ & $\begin{array}{l}\text { Promotes } \\
\text { pedestrian } \\
\text { oriented } \\
\text { development? }\end{array}$ & $\begin{array}{l}\text { Connection to } \\
\text { transit }\end{array}$ \\
\hline \multicolumn{6}{|c|}{ Case Study 1 - Network 2011 et al. } \\
\hline Central Area & $\begin{array}{l}\text { Residential, } \\
\text { business, } \\
\text { government, } \\
\text { recreation, culture }\end{array}$ & Yes & $\begin{array}{l}\text { Should not develop } \\
\text { too quickly; should } \\
\text { not be completely } \\
\text { limited. }\end{array}$ & No mention & $\begin{array}{l}\text { Current transit } \\
\text { access } \\
\text { adequate. }\end{array}$ \\
\hline $\begin{array}{l}\text { Major } \\
\text { Subcentres }\end{array}$ & $\begin{array}{l}\text { Commercial } \\
\text { (office/retail), } \\
\text { institutional, } \\
\text { residential. }\end{array}$ & Yes & Yes & $\begin{array}{l}\text { Most density } \\
\text { within walking } \\
\text { distance of } \\
\text { transit. }\end{array}$ & $\begin{array}{l}\text { High quality } \\
\text { transportation } \\
\text { services to } \\
\text { connect sub- } \\
\text { centres. }\end{array}$ \\
\hline $\begin{array}{l}\text { Minor } \\
\text { Subcentres }\end{array}$ & $\begin{array}{l}\text { Office, retail, } \\
\text { residential }\end{array}$ & $\begin{array}{l}\text { Yes to a lesser } \\
\text { extent. }\end{array}$ & $\begin{array}{l}\text { Yes to a lesser } \\
\text { extent }\end{array}$ & No mention & \\
\hline \multicolumn{6}{|c|}{ Case Study 2 - Transit City et al. } \\
\hline Centres & $\begin{array}{l}\text { Emphasizes a mix } \\
\text { of residential and } \\
\text { employment } \\
\text { growth. }\end{array}$ & Yes & Yes & $\begin{array}{l}\text { Yes (enforced } \\
\text { via Secondary } \\
\text { Plans \& Site } \\
\text { Plan Control) }\end{array}$ & \\
\hline Avenues & $\begin{array}{l}\text { Emphasizes } \\
\text { residential growth } \\
\text { with at grade } \\
\text { retail. }\end{array}$ & $\begin{array}{l}\text { Yes (underlying } \\
\text { designation } \\
\text { Mixed Use) } \\
\text { No (underlying } \\
\text { designation } \\
\text { neighbourhood) }\end{array}$ & $\begin{array}{l}\text { Yes (ground floor } \\
\text { retail) }\end{array}$ & $\begin{array}{l}\text { Yes (enforced } \\
\text { via Avenue } \\
\text { studies, Mid- } \\
\text { Rise Guidelines, } \\
\text { \& Site Plan } \\
\text { Control) }\end{array}$ & \\
\hline $\begin{array}{l}\text { Employment } \\
\text { Districts }\end{array}$ & $\begin{array}{l}\text { Emphasizes job } \\
\text { intensification. }\end{array}$ & No & Yes & $\begin{array}{l}\text { No specific } \\
\text { policy }\end{array}$ & \\
\hline $\begin{array}{l}\text { Neighbourh- } \\
\text { oods }\end{array}$ & $\begin{array}{l}\text { Emphasizes infill } \\
\text { residential } \\
\text { development and } \\
\text { small scale retail. }\end{array}$ & $\begin{array}{l}\text { No (small scale } \\
\text { infill only) }\end{array}$ & $\begin{array}{l}\text { No (small scale } \\
\text { infill only) }\end{array}$ & $\begin{array}{l}\text { No specific } \\
\text { policy }\end{array}$ & \\
\hline
\end{tabular}

Sources - (City of Toronto, 2010; Municipality of Metropolitan Toronto, 1981) 
Appendix 2 - Sources used in the GIS analysis

City of Toronto. Research and Information, City Planning Division. (2012). Toronto employment survey 2011.

Retrieved from website:

http://www1.toronto.ca/wps/portal/contentonly?vgnextoid=c7ac186e20ee0410VgnVCM10000071d60f89RC

RD

City of Toronto. City Planning, (2010). Toronto official plan. Retrieved from website:

http://www1.toronto.ca/static_files/CityPlanning/PDF/chapters1_5_dec2010.pdf

DMTI Spatial Inc. (2012). CanMap RouteLogistics "Transportation Stops (TRS)". Scholars GeoPortal. Retrieved from

http://geo2.scholarsportal.info/\#_lang=en\&layersInfo_895727599_opacity:1\&order:0;\&BingMapsRoad_opa city:1;;\&basemap=Bing\%20Maps\%20Road\&layers@=895727599;\&extent_xmin:-

8864678.686077315\&ymin:5339699.438531706\&xmax:-

8592562.86538222\&ymax:5523454.054529181\&spatialReference_wkid:102100

Municipality of Metropolitan Toronto. Planning Department, Long Range Planning Division. (1976). Metroplan central area and sub centres.

Municipality of Metropolitan Toronto. (1981). Official plan for the urban structure. Toronto, Cdn: The Municipality of Metropolitan Toronto.

Statistics Canada. (1981). 1981 Census of Canada census tract boundary files[SHAPEFILE]. Retrieved from http://maps.library.utoronto.ca/cgi-bin/files.pl?idnum=491

Statistics Canada. (1981) Population, 1981. Retrieved February 2014 from http://dc1.chass.utoronto.ca.myaccess.library.utoronto.ca/census/

Statistics Canada. (1981). Private Household income - all households - average income. Retrieved February 2014 from http://dc1.chass.utoronto.ca.myaccess.library.utoronto.ca/census/

Statistics Canada. (2011). Census Tracts - Digital Boundary File (CT-DBF), 2011 Census. Scholars GeoPortal. Retrieved from http://geo2.scholarsportal.info/\#_lang=en\&layersInfo_3187590914_opacity:1\&order:0;\&BingMapsRoad_op acity:1;;\&basemap=Bing\%20Maps\%20Road\&layers@=3187590914;\&extent_xmin:8864678.686077315\&ymin:5339699.438531706\&xmax:8592562.86538222\&ymax:5523454.054529181\&spatialReference_wkid:102100

Statistics Canada. (2011) Population, 2011 (v1). Retrieved February 2014 from http://dc1.chass.utoronto.ca.myaccess.library.utoronto.ca/census/

Statistics Canada. (2011). Total income in 2010 of population aged 15 years and over; Both sexes: Average income \$; Both sexes (v2310). Retrieved February 2014 from http://dc1.chass.utoronto.ca.myaccess.library.utoronto.ca/census/ 
Appendix 3- Sources used to determine the configuration of various iterations

Network 2011

Get Toronto Moving Transportation Committee. (2014a). Network 2011 subways. Retrieved from http://www.gettorontomoving.ca/Network_2011_Subways.html.

Toronto Transit Commission. Metropolitan Toronto, (1985). Network 2011: A rapid transit plan for Toronto.

Let's Move

Bow, J. (2013, May 9). Network 2011 -- to think of what could have been. Retrieved from http://transit.toronto.on.ca/subway/5111.shtml.

Levy, E. Neptis Foundation, (2013). Rapid transit in Toronto: A century of plans, progress, politics \& paralysis.

Mackenzie, R. (2014, March 24). Latest transit Toronto news. Retrieved from http://transit.toronto.on.ca/.

Rapid Transit Expansion Plan

Levy, E. Neptis Foundation, (2013). Rapid transit in Toronto: A century of plans, progress, politics \& paralysis.

Transit City Phase 1\&2

Dotan, H. (2013, October 31). Poll position: LRT most popular choice for Scarborough transit. Torontoist. Retrieved from http://torontoist.com/2013/10/poll-position-toronto-prefers-lrt-to-subway-in-scarborough/.

Frequently asked questions about Toronto's subway and the Scarborough rt. (2013, September 6). Retrieved from http://transit.toronto.on.ca/subway/5002.shtml

Munro, S. (2013, April 29). A new transit deal for Scarborough?. Torontoist. Retrieved from http://torontoist.com/2013/04/a-new-transit-deal-for-scarborough/

Steer Davies Gleave. Metrolinx, (2009). Sheppard-finch LRT benefits case

Toronto Transit Commission. Transit City Department, (2010a). Eglinton crosstown LRT.

Toronto Transit Commission. Transit City Department, (2010b). Finch west LRT: Stops and interchange stations.

Toronto Transit Commission. Transit City Department, (2010c). Sheppard east LRT.

Toronto Transit Commission. (2010d). Eglinton crosstown light rail transit; transit project assessment; environmental project report. Retrieved from http://thecrosstown.ca/sites/default/files/pdf/reports/CrosstownLRT-Environmental-Project-Report/appendixn-travel-demand-forecasting-report.pdf.

Toronto Transit Commission, \& Metrolinx (n.d.). Eglinton-Scarborough crosstown. Retrieved from http://torontopubliclibrary.typepad.com/.a/6a00e5509ea6a18834017d3c6240cf970c-pi.

Toronto Transit Commission, \& Metrolinx (2010). Scarborough rt. Retrieved from http://www.ttc.ca/images/About_the_TTC/Transit_city/map_Scarborough_RT.jpg.

VivaNext. (2013, December 5). 'holey' 'moley' tunnelling is complete!. Retrieved from http://vivanext.com/blog/tag/subway/.

Ford Memorandum of Understanding (MOU) 
Bow, J. (2012, April 3). The Eglinton-Scarborough-crosstown LRT. Retrieved from http://transit.toronto.on.ca/streetcar/4124.shtml.

Burda, C., \& Haines G. (2011b). New Transit Plan for Toronto. Pembina Institute.

Remember rob ford's transportation plan? (2011, December 8). BlogTO. Retrieved from http://www.blogto.com/city/2011/12/remember_rob_fords_transportation_plan/.

VivaNext. (2013, December 5). 'holey' 'moley' tunnelling is complete!. Retrieved from http://vivanext.com/blog/tag/subway/.

Transit City Phase 1 with Scarborough Subway

Dotan, H. (2013, October 31). Poll position: LRT most popular choice for Scarborough transit. Torontoist. Retrieved from http://torontoist.com/2013/10/poll-position-toronto-prefers-lrt-to-subway-in-scarborough/. 
Appendix 4 - Case Study Timelines

Case Study 1 - Network 2011 et al.

1985 - March - TTC adopts the Network 2011 plan. The following line segments were included in the proposal:

- a subway along Sheppard;

- a busway along Eglinton, to eventually be converted to a full subway;

- a Downtown relief line (DRL).

1986 - June - Metropolitan Toronto Council adopts parts of the Network 2011 plan (the Sheppard Subway).

1987 - September - Majority Provincial Liberal Government elected under David Peterson.

1990 - April - The Province announces Let's Move, a statement of their intent with regards to public transit infrastructure spending. The following line segments were included in the proposal:

- a shortened version of the Sheppard line;

- a shortened version of the Eglinton line;

- a subway loop connecting the Spadina and Yonge lines via Steeles;

- extension of the Bloor Danforth line to Sherway Gardens;

- $\quad$ an extension of the Scarborough RT to Sheppard and Markham Road.

1990 - September - Majority NDP government elected under Bob Rae

1993 - February - NDP release the Rapid Transit Expansion plan (RTEP). The NDP committed to financing 75 percent of the capital costs of the following line segments:

- a shortened version of the Sheppard line;

- a shortened version of the Eglinton line;

- an extension of the Spadina subway to Steeles;

- $\quad$ an extension of the Scarborough RT to Markham Road at Sheppard.

1994 - March - Metropolitan Toronto Council agrees to the construction of the Sheppard and Eglinton lines, but not the Spadina or Scarborough RT extension until adequate funding became available.

1995 - June - Majority Conservative government elected under Mike Harris

1995 - July - The Conservative party announces that they would proceed with transit projects in a phased manner, beginning with the Sheppard subway. The Eglinton project was deferred indefinitely and never completed. 
Case Study 2 - Transit City et al.

2006 - June- Metrolinx created by the Majority Liberal Ontario government under Dalton McGuinty (it was originally called the Greater Toronto Transportation Authority).

2006 - October - Incumbent City of Toronto Mayor, David Miller, announces his vision for transit expansion based on Light Rail Transit within the municipal Right of Ways during the Mayoral election campaign.

2006 - November - Miller re-elected.

2007 - March - the TTC officially approved the Transit City Light Rail Plan, including 8 lines. No funding strategy was announced.

2007 - June - Incumbent Premier, Dalton McGuinty, announces his intention to provide \$17.5 billion to public transit infrastructure in the MoveOntario 2020 plan

2007 - September - the Greater Toronto Transportation Authority is renamed Metrolinx

2007 - October - McGuinty and the Ontario Liberal party are re-elected with a majority government.

2007 - November - The TTC approved 4 priority projects which include:

- Eglinton Crosstown LRT;

- Finch West LRT;

- Sheppard East LRT;

- Scarborough RT conversion to LRT.

2008 - November - Metrolinx releases the Big Move Plan.

2009 - May - Metrolinx board is changed from one comprised partially of municipally elected officials to a 15 person board appointed by the province.

2009 - June - The TTC's 4 priority projects were selected as priority projects in Metrolinx Big Move Plan

2009 - Spring - The province includes $\$ 11.5$ billion in funding for transit projects in their budget.

2010 - March - \$4 billion of provincial funding to the priority projects is cancelled amid the great recession. The four projects are reduced in scope significantly for their first 'phase'. Construction and funding for the second 'phase' of construction to be achieved through alternative funding mechanisms.

2010 - December - Mayor Rob Ford is elected Mayor of the City of Toronto.

2011 - March - Ford and the McGuinty Provincial government reach a memorandum of understanding MOU, which includes the following line segments: 
- a subway along Sheppard Ave. connecting the Spadina and Yonge lines as well as extending from Don Mills station to Scarborough Town Centre;

- a completely underground Eglinton LRT;

- the conversion of the Scarborough RT to LRT.

2011 - October - The Liberal Party of Ontario is re-elected with a Minority government under Dalton McGuinty.

2012 - February - Karen Stintz, the Chair of the TTC circulates "a petition calling on city council to bring forward a motion to decide on Transit City" (Global News, 2012).

2012 - February - Council votes 25-18 to reinstate the aboveground version of Eglinton, and the LRT along Finch.

2012 - March - Council votes to build the Sheppard East LRT instead of the subway.

2013 - January - Kathleen Wynne takes over as leader of the Minority Liberal government.

2013 - Summer - during a provincial by-election in Scarborough, the liberal party promises to rebuild the Scarborough RT as a subway.

2013 -October - Toronto City Council debated their preferences for the Scarborough corridor and voted 24 to 20 to replace the LRT plan for Scarborough with a three stop subway extension 
Appendix 5 - Census Tracts within Walking Distance of various iterations
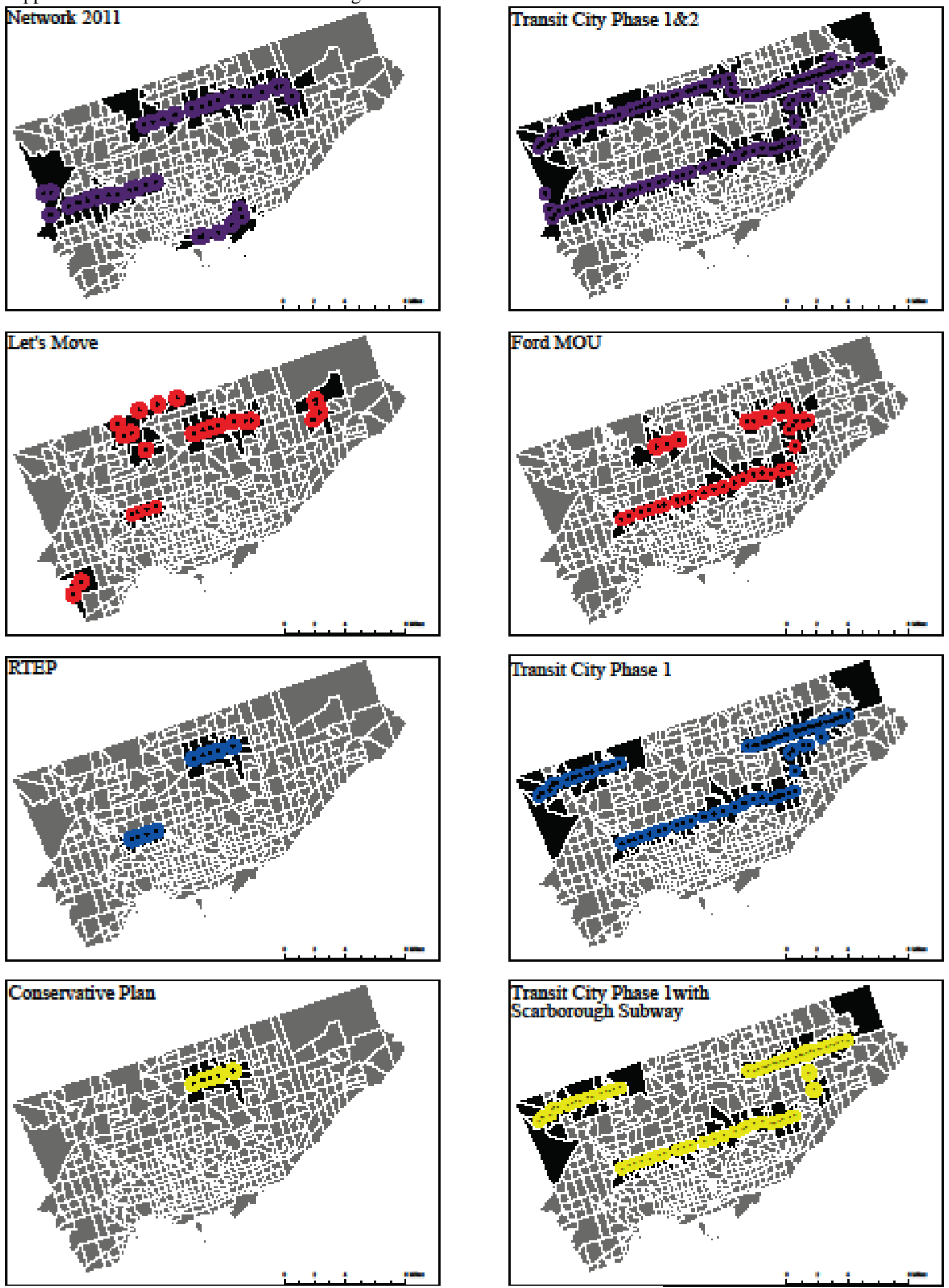

Sources - Appendix 2,3 
Appendix 6 - Employment Districts
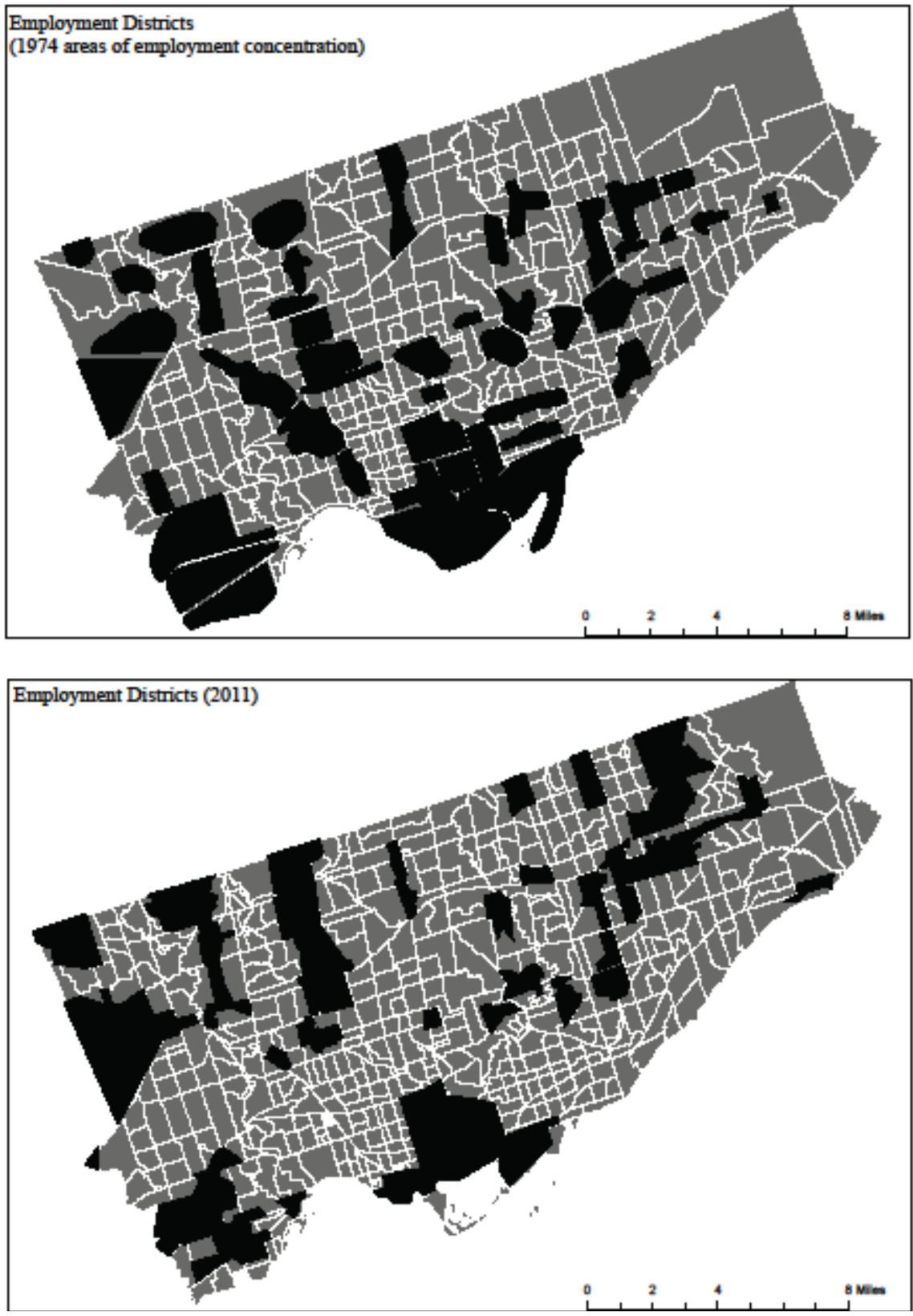

Sources - (City of Toronto, 2012; Municipality of Metropolitan Toronto, 1976) 
Appendix 7 - Sources for costs

\begin{tabular}{|c|c|c|}
\hline \multicolumn{3}{|l|}{ Costs } \\
\hline Iteration & Cost & source \\
\hline \multicolumn{3}{|r|}{ Case 1 Network 2011 et al. } \\
\hline Network 2011 & $\$ 2,718,000,000$ & $\begin{array}{l}\text { Toronto Transit Commission. Metropolitan Toronto, (1985a). Network 2011: } \\
\text { A rapid transit plan for Toronto }\end{array}$ \\
\hline Let's Move & $\$ 4,600,000,000$ & $\begin{array}{l}\text { James, R. (1993). Transit advocates fight transit expansion. Toronto Star. } \\
\text { Retrieved from } \\
\text { http://ezproxy.lib.ryerson.ca/login?url=http://search.proquest.com.ezproxy.lib } \\
\text {.ryerson.ca/docview/436937632?accountid=13631 }\end{array}$ \\
\hline RTEP & $\$ 1,900,000,000$ & $\begin{array}{l}\text { Toronto Transit Commission. (1995). Toronto's rapid transit expansion } \\
\text { program. Tunnelling and Underground Space Technology, 10(1), 53-63. }\end{array}$ \\
\hline ConservPlan & $\$ 1,000,000,000$ & $\begin{array}{l}\text { Levy, E. Neptis Foundation, (2013). Rapid transit in Toronto: A century of } \\
\text { plans, progress, politics \& paralysis. }\end{array}$ \\
\hline \multicolumn{3}{|r|}{ Case 2 - Transit City et al. } \\
\hline $\begin{array}{l}\text { Transit City } \\
\text { P12 }\end{array}$ & $\$ 11,500,000,000$ & $\begin{array}{l}\text { Levy, E. Neptis Foundation, (2013). Rapid transit in Toronto: A century of } \\
\text { plans, progress, politics \& paralysis. }\end{array}$ \\
\hline FordMOU & $\$ 12,400,000,000$ & $\begin{array}{l}\text { Burda, C., \& Haines G. (2011b). New Transit Plan for Toronto. Pembina } \\
\text { Institute. }\end{array}$ \\
\hline $\begin{array}{l}\text { TransitCityP1 } \\
\text { noScarb }\end{array}$ & $\$ 8,400,000,000$ & $\begin{array}{l}\text { Hains, D., \& Dotan, H. (2013, October 8). Subway vs lrt: You do the math on } \\
\text { scarborough transit. Torontoist. Retrieved from Subway vs LRT: You Do the } \\
\text { Math on Scarborough Transit }\end{array}$ \\
\hline $\begin{array}{l}\text { Transit City } \\
\text { wScarb }\end{array}$ & $\$ 10,100,000,000$ & $\begin{array}{l}\text { Hains, D., \& Dotan, H. (2013, October 8). Subway vs lrt: You do the math on } \\
\text { scarborough transit. Torontoist. Retrieved from Subway vs LRT: You Do the } \\
\text { Math on Scarborough Transit }\end{array}$ \\
\hline
\end{tabular}


Appendix 8 - Land use Regulations

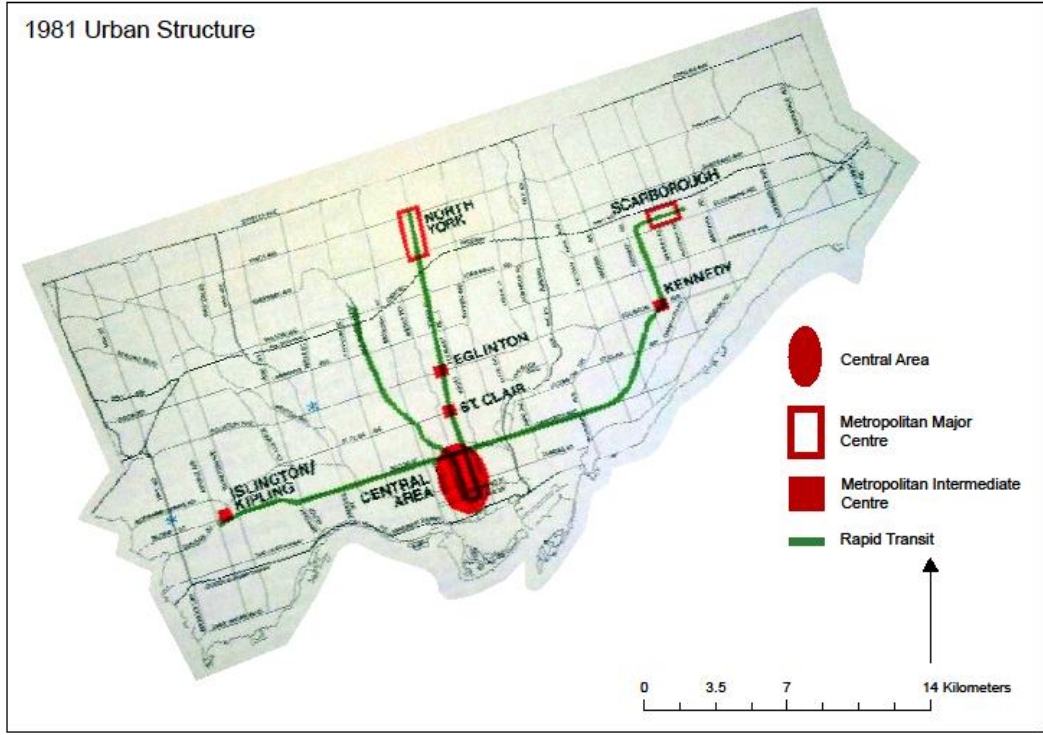

Sources - (City of Toronto, 2010; Municipality of Metropolitan Toronto, 1981)

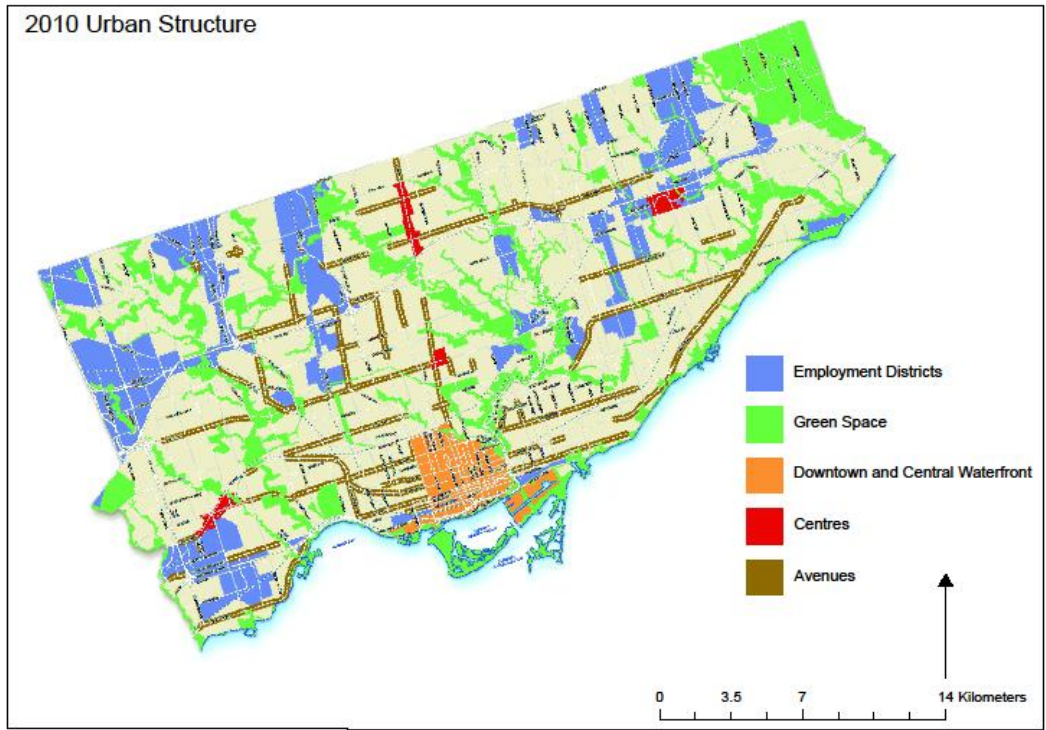

Sources - (City of Toronto, 2010; Municipality of Metropolitan Toronto, 1981) 
Appendix 9 - Graphic Representations of various iterations

Graph Analysis: Case 1 - Network 2011 et al. Existing Network (1985)

Network 2011

Let's Move

Rapid Transit Expansion Program

Conservative Rapid Transit Plan
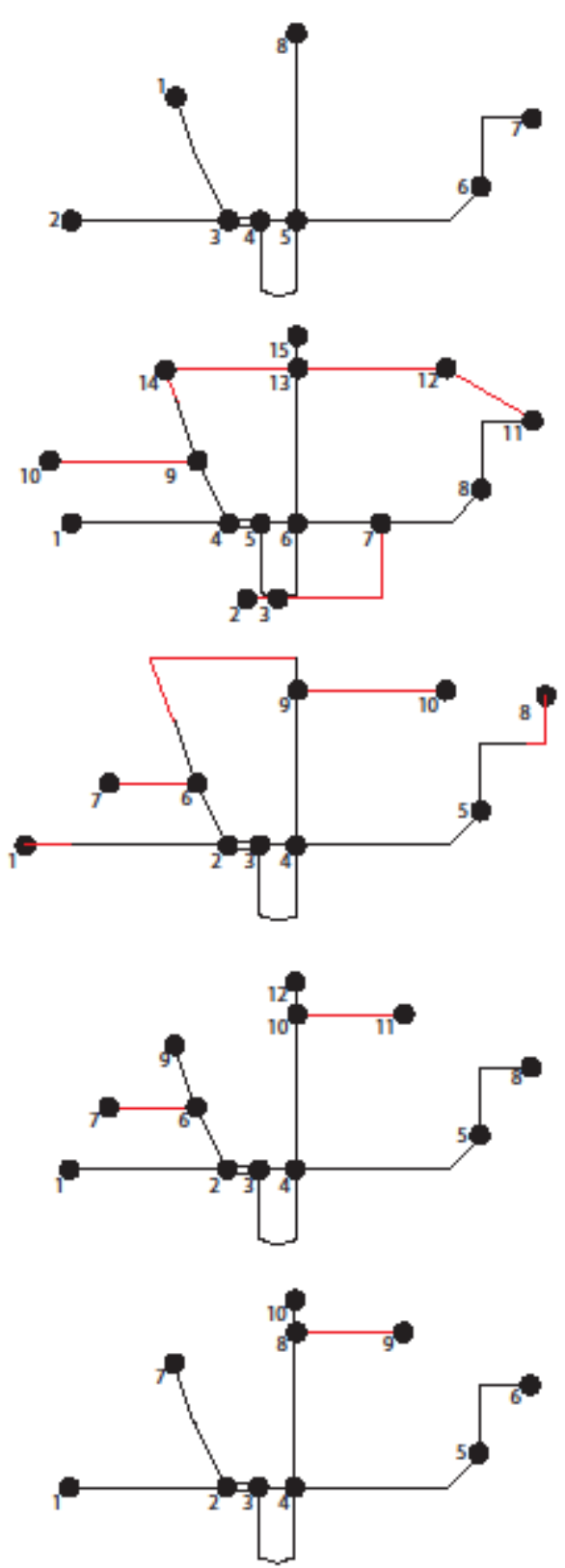
Graph Analysis: Case 2 - Transit City and following iterations Existing

Network 2007

Transit City Phase $1 \& 2$

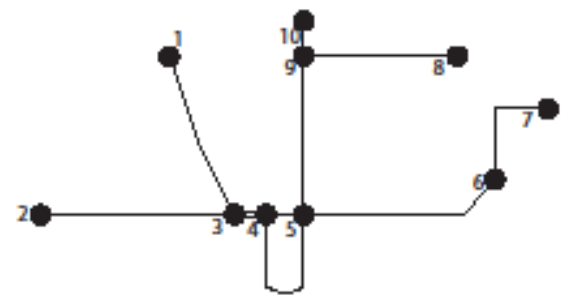

Ford MOU

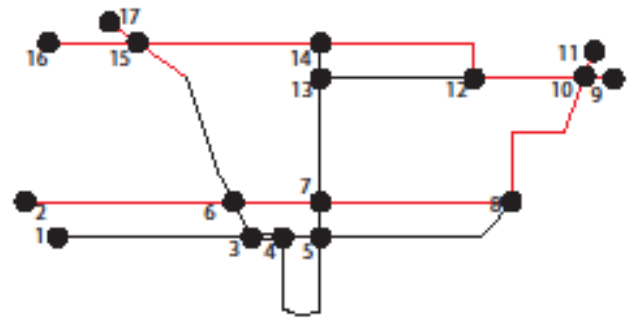

Scarb Subway and original Transit City
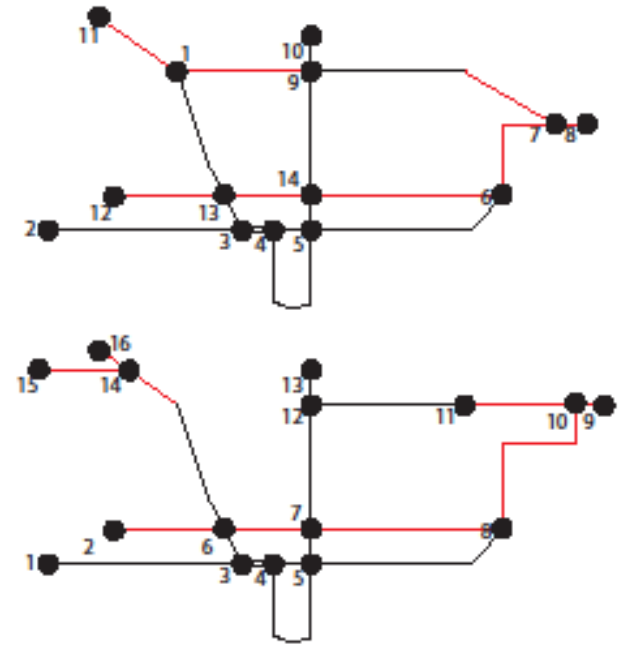

Scarb Subway and original Transit City

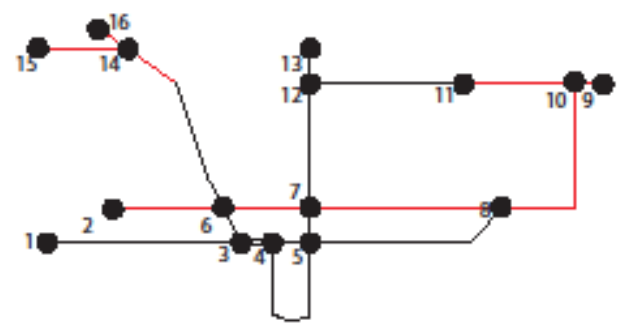

Sources -Appendix 3 


\section{Section 10 - Bibliography}

Addie, J. D. (2010). Transportation governance at the crossroads the case of Toronto. Department of Geography, York University, Toronto, Canada.

Adel, A., \& Bow, J. (2012, July 5). The Sheppard subway. Retrieved from http://transit.toronto.on.ca/subway/5110.shtml.

Alshalalfah, W., \& Shalaby, A. S. (2007). Case Study: Relationship of Walk Access Distance to Transit with Service, Travel, and Personal Characteristics. Journal of Urban Planning and Development, 133 (2) 114-18.

Armstrong, J. (2014, March 13). Lrt vs. scarborough subway: where do the mayoral candidates stand?. Global News. Retrieved from http://globalnews.ca/news/1206056/lrt-vs-scarborough-subway-where-do-the-mayoralcandidates-stand/.

Bakht, M. N. (2013). Toronto "transit city" and its history [Web]. Retrieved from http://www.youtube.com/watch?v=eDFQgAKfX4w.

Barber, J. (1994, March 10). TORONTO Subway stew missing some key ingredients. The Globe and Mail. Retrieved from http://ezproxy.lib.ryerson.ca/login?url=http://search.proquest.com.ezproxy.lib.ryerson.ca/docview/38519662 8 ?accountid=13631

Bird, R., \& Slack, E. (2007). An approach to metropolitan governance and finance. Environment and Planning C: Government and Policy, 25, 729-755. doi: 10.1068/c0623

Boudreau, J.A., P. Hamel, B. Jouve, \& R. Keil. (2006). Comparing metropolitan governance: The cases of Montreal and Toronto. Progress in Planning, 66, 7-59.

Boudreau, J.-A. (2007). Making new political spaces: Mobilizing spatial imaginaries, instrumentalizing spatial practices, and strategically using spatial tools. Environment \& Planning A, 39(11), 2593- 2611.

Bourne L. S. (1989). Are New Urban Forms Emerging? Empirical Tests for Canadian Urban Areas. The Canadian Geographer, 33 (4), 312-28.

Bow, J. (2011, June 26). The Eglinton West subway. Retrieved from http://transit.toronto.on.ca/subway/5112.shtml.

Bow, J. (2012, April 3). The Eglinton-Scarborough-crosstown LRT. Retrieved from http://transit.toronto.on.ca/streetcar/4124.shtml.

Bow, J. (2013, May 9). Network 2011 -- to think of what could have been. Retrieved from http://transit.toronto.on.ca/subway/5111.shtml.

Bradburn, J. (2012, March 20). Retro T.O.: The Eglinton subway we almost had. The Grid. Retrieved from http://www.thegridto.com/city/politics/retro-t-o-the-eglinton-subway-we-almost-had/.

Burda, C., \& Haines G. (2011a). Making Tracks to Torontonians. Pembina Institute.

Burda, C., \& Haines G. (2011b). New Transit Plan for Toronto. Pembina Institute.

Burda, C., \& Haines, G. (2012). Drivers choice: Options to manage gridlock and fund rapid transit in the GTA. Pembina Institute. 
Byers, J. (1990, July 31). Wanted: $\$ 250,000$ to study $\$ 5$ billion transit plan. Toronto Star. Retrieved from http://ezproxy.lib.ryerson.ca/login?url=http://search.proquest.com.ezproxy.lib.ryerson.ca/docview/43623299 4?accountid= 13631

CBC News. (2014, March 13). Kathleen Wynne rules out gas tax, HST hike for transit. CBC News. Retrieved from http://www.cbc.ca/news/canada/toronto/kathleen-wynne-rules-out-gas-tax-hst-hike-for-transit-1.2571149.

Chong, G. Toronto Transit Infrastructure Limited, (2012). Toronto transit: Back on track. Retrieved from website: http://www.toronto.ca/legdocs/mmis/2012/ex/bgrd/backgroundfile-44984.pdf.

Church, E., \& Rogers, K. (2013, October 8). Toronto council votes for Scarborough subway extension. The Globe and Mail. Retrieved from http://www.theglobeandmail.com/news/toronto/scarborough-subway-debatebegins-with-proposed-cost-to-toronto-homeowners/article14745918/

City of Toronto. City Planning, (2010). Toronto official plan. Retrieved from website: http://www1.toronto.ca/static_files/CityPlanning/PDF/chapters1_5_dec2010.pdf.

City of Toronto. Research and Information, City Planning Division. (2012). Toronto employment survey 2011. Retrieved from website: http://www1.toronto.ca/wps/portal/contentonly?vgnextoid=c7ac186e20ee0410VgnVCM10000071d60f89RC RD.

CNW Group. (2006, October 24). David miller unveils vision for making Toronto a transit city. HighBeam Business, Retrieved from http://business.highbeam.com/1758/article-1G1-153264475/david-miller-unveils-visionmaking-toronto-transit.

Coleman, J., Kennedy, C., Maclean, H., Miller E., \& Shalaby, A. (2005). The Four Pillars of Sustainable Urban Transportation. Transport Reviews, 25(4), 393-414.

Coopers \& Lybrand Consulting Group \& IBI Group. Metropolitan Toronto. (1991). Sheppard subway financing study: Final report.

Coutts, J. (1994, March 11). Metro approves two subway lines for $\$ 1.9$ billion Councillors vote 19-12 to construct on Sheppard East and Eglinton West. The Globe and Mail. Retrieved from http://ezproxy.lib.ryerson.ca/login?url=http://search.proquest.com.ezproxy.lib.ryerson.ca/docview/38525392 8 ? accountid= 13631

Daniels, R., \& Mulley, C. (2013). Explaining walking distance to public transport: The dominance of public transport supply. The journal of transport and land use, 6(2), 5-20. Retrieved from http://jtlu.org.

DMTI Spatial Inc. (2012). CanMap RouteLogistics "Transportation Stops (TRS)". Scholars GeoPortal. Retrieved from http://geo2.scholarsportal.info/\#_lang=en\&layersInfo_895727599_opacity:1\&order:0;\&BingMapsRoad_opa city:1;;\&basemap=Bing\%20Maps\%20Road\&layers@=895727599;\&extent_xmin:8864678.686077315\&ymin:5339699.438531706\&xmax:8592562.86538222\&ymax:5523454.054529181\&spatialReference_wkid:102100.

Dotan, H. (2013, October 31). Poll position: LRT most popular choice for Scarborough transit. Torontoist. Retrieved from http://torontoist.com/2013/10/poll-position-toronto-prefers-lrt-to-subway-in-scarborough/. 
El-Geneidy, A., Grimsrud, M., Wasfi, R., Tétreault, P., \& Surprenant-Legault, J. (2014). New evidence on walking distances to transit stops: Identifying redundancies and gaps using variable service areas. Transportation, 41(1), 193-210.

English, J. (2012, July 2012). The transit planning process in Toronto and the GTA. Retrieved from http://urbantoronto.ca/news/2012/07/transit-planning-process-toronto-and-gta.

Federation of Canadian Municipalities, (2006). Building prosperity from the ground up: Restoring municipal fiscal balance. Retrieved from website: www.fcm.ca.

Flaherty, J. M. Government of Canada, Ministry of Finance. (2013). Jobs growth and long-term prosperity: Economic action plan 2013 (eap13). Retrieved from website: http://www.budget.gc.ca/2013/doc/plan/budget2013-eng.pdf

Florida, Richard. (2002) The Rise of the Creative Class. New York: Harper Collins.

Frequently asked questions about Toronto's subway and the Scarborough rt. (2013, September 6). Retrieved from http://transit.toronto.on.ca/subway/5002.shtml.

Frisken, F., Bourne, L. S., Gad, G., \& Murdie, R. A. (2000). Governance and social sustainability: The Toronto experience. In M. Polese \& R. Stern (Eds.), The social sustainability of Cities: Diversity and the management of change. Retrieved from http://site.ebrary.com/lib/oculryerson/docDetail.action?docID=10219217\&page=88.

Get Toronto Moving Transportation Committee. (2014a). Network 2011 subways. Retrieved from http://www.gettorontomoving.ca/Network_2011_Subways.html.

Get Toronto Moving Transportation Committee. (2014b). Plans. Retrieved from http://www.gettorontomoving.ca/Plans.php.

Global News. (2012, February 6). Timeline: A history of transit city. Retrieved from http://globalnews.ca/news/207955/timeline-a-history-of-transit-city/.

Golden, A., \& Knowles, S. (2012). Governance gridlock. Informally published manuscript, School of Urban and Regional Planning, Ryerson University, Toronto, Canada.

Gormick, G. (1990, May). Toronto: Back on track?. Railway Age, 191(5), 67-69, 83.

Guerra, E., Cervero, R., \& Tischler, D. (2011). The half-mile circle: Does it best represent transit station catchments? Working Paper, Institute of Transportation studies, university of California, Berkeley.

Hambleton, R., \& Gross, J. S. (2007). From governance to governing. In R. Hambleton \& J. Gross (Eds.), Governing Cities in a Global Era. Palgrave Macmillan.

Hatzopoulou, M. \& E.J. Miller. "Institutional integration for sustainable transportation policy in Canada." Transport Policy 15 (2008): 149-162.

HDR. Greater Toronto Transportation Authority, (2008). Costs of Road Congestion in the Greater Toronto and Hamilton Area.

Hjartarson, J. (2011) Lecture on Ontario Municipal Politics. Personal Collection of J. Hjartarson, University of Toronto, Toronto, Ontario, Canada. 
Hopper, T., Alcoba, N., \& Bosanac, A. (2013, October 8). Toronto city council votes to build Scarborough subway extension instead of LRT. National Post. Retrieved from http://news.nationalpost.com/2013/10/08/torontocity-council-votes-to-build-scarborough-subway-extension-instead-of-lrt/

Horak, M. Making Multilevel Governance Work: Overcoming Coordination Challenges in the City of Toronto. University of Western Ontario Department of Political Science, London, ON., 2008.

IBI Group The Greater Toronto Coordinating Committee, (1990). Summary report: Greater toronto area urban structure concepts study.

Infrastructure Canada. (2013, September 16). Gas tax fund. Retrieved from http://www.infrastructure.gc.ca/prog/gtffte-eng.html.

James, R. (1993). Transit advocates fight transit expansion. Toronto Star. Retrieved from http://ezproxy.lib.ryerson.ca/login?url=http://search.proquest.com.ezproxy.lib.ryerson.ca/docview/43693763 2?accountid=13631

Kalinowski, T. (2007, June 16). A \$17.5b transit promise. Toronto Star. Retrieved from http://www.thestar.com/news/ontario/2007/06/16/a_175b_transit_promise.html.

Kalinowski, T., \& Powell , B. (2013, October 8). Scarborough subway confirmed by Toronto council. Toronto Star. Retrieved from http://www.thestar.com/news/gta/2013/10/08/scarborough_subway_confirmed_by_toronto_council.html

Kalinowski, T. (2013, October 11). Will the Scarborough subway kill LRT in Toronto? Toronto Star. Retrieved from http://www.thestar.com/news/gta/2013/10/11/will_the_scarborough_subway_kill_lrt_in_toronto.html

Keil, R. \& Douglas, Y. (2008). Transportation: the bottleneck of regional competitiveness in Toronto. Environment and Planning C: Government Policy, 26, 728-751.

Kennedy, C., \& Derrible, S. (2010a). Characterizing metro networks: state, form, and structure. Transportation, 37, 275-297. doi: 10.1007/s11116-009-9227-7.

Kennedy, C., \& Derrible, S. (2010b). Evaluating, comparing, and improving metro networks: Application to plans for Toronto, Canada. Transportation Research Record, 2146, 43-51. doi: 10.3141/2146-06.

Kitchen, H. Residential and Civil Construction Alliance of Ontario, (2008). Financing public transit and transportation in the greater Toronto area and Hamilton: Future initiatives.

Krawchenko, T. (2011). Regional special purpose bodies for transportation and transit in Canada: Case studies of Translink and Metrolinx. Canadian Journal of Regional Science, 34(1), 1-8.

Levy, E. Neptis Foundation, (2013). Rapid transit in Toronto: A century of plans, progress, politics \& paralysis. Mackenzie, R. (2014, March 24). Latest transit Toronto news. Retrieved from http://transit.toronto.on.ca/. Meligrana, J. F. (1999). Toward regional transportation governance: A case study of greater Vancouver. Transportation, 26, 359-380.

Metrolinx. (2008) The Big Move: Transforming Transportation in the Greater Toronto and Hamilton Area.

Metrolinx. (2013). Investment strategy. Retrieved from website: http://www.metrolinx.com/en/regionalplanning/funding/investment_strategy.aspx. 
Millward, Hugh. (2008). Evolution of Population Densities: Five Canadian Cities, 1971-2001. Urban Geography, $29,616-638$.

Millward H. \& Bunting T. (2008). Patterning in urban population densities: a spatiotemporal model compared with Toronto 1971 - 2001. Environment and Planning A, 40, 283-302.

Mitra, R. (2013) Lecture on Transportation Networks. Personal Collection of R. Mitra, Ryerson Univerity, Toronto, Ontario, Canada.

Morrow, A. (2014, March 13). Wynne rejects hike in sales, gas taxes for transit. The Globe and Mail. Retrieved from http://www.theglobeandmail.com/news/politics/ontario-wont-hike-hst-or-gas-tax-to-pay-for-transitwynne-says/article17476325/

Municipality of Metropolitan Toronto. Planning Department , Long Range Planning Division. (1976). Metroplan central area and sub centres.

Municipality of Metropolitan Toronto. (1981). Official plan for the urban structure. Toronto, Cdn: The Municipality of Metropolitan Toronto.

Munro, S. (2013, April 29). A new transit deal for Scarborough?. Torontoist. Retrieved from http://torontoist.com/2013/04/a-new-transit-deal-for-scarborough/.

Organisation for Economic Co-Operation and Development. (2009). OECD territorial reviews: Toronto Canada. OECD Publishing.

Orr, P., \& Perry, A. (2010). A history of the queen and downtown relief line subway proposals. Retrieved from http://www.drlnow.ca/ .

Osbaldeston, M. (2011). Unbuilt Toronto 2: More of the city that might have been. Toronto, Cdn: Dundurn.

Remember rob ford's transportation plan? (2011, December 8). BlogTO. Retrieved from http://www.blogto.com/city/2011/12/remember_rob_fords_transportation_plan/.

Rodrigue, J. P., Comtois, C., \& Slack, B. (2009). The geography of transportation systems. (2nd ed.). New York: Routledge.

Sancton, A. (2005). The governance of metropolitan areas in Canada. Public Administration and Development, 25, 317-327. doi: 10.1002/pad.386

Savoie, D. (1999). The Rise of Court Governance in Canada. Canadian Journal of Political Science 32(4), 635-664.

Savoie, D. (2006). Primus: There is No Longer Inter or Pares. In M. Charlton and P. Barker (Eds.) Crosscurrents: Contemporary Political Issues (5th ed) (pp. 180-213). Toronto: Thompson Nelson.

Savoie, D. (2009). Power at the Apex: Executive Dominance. In by J. Bickerton, \& A. Gagnon(Eds.) Canadian Politics (5th ed.) (pp. 115-132). Toronto: University of Toronto Press.

Searle, P., \& Nichols, B. Ministry of Transportation, News. (2013). Minister's statement on final transit investment strategy report.

Smith, M. (1986a, February 8). Network 2011: The battle over who gets what municipalities stake out claims for more transit. Toronto Star. Retrieved from

http://ezproxy.lib.ryerson.ca/login?url=http://search.proquest.com.ezproxy.lib.ryerson.ca/docview/43541102 3 ?accountid=13631 
Smith, M. (1986b, June 17). Toronto Council backs Sheppard Ave. subway. Toronto Star. Retrieved from http://ezproxy.lib.ryerson.ca/login?url=http://search.proquest.com.ezproxy.lib.ryerson.ca/docview/43544560 7 ? accountid= 13631

Simpson, J. (2001). The Friendly Dictatorship. Toronto: McClelland and Stewart Ltd.

Slack, E. (2004). Models of government structure at the local level. Working Paper, Institute of Intergovernmental Relations, Queen's University, Kingston, ON, Canada. Retrieved from http://site.ebrary.com/lib/oculryerson/docDetail.action?docID=10083106.

Slack, E. (2009). A Guide to Municipal Finance. United Nations Human Settlements Program. 2009. Retrieved from http://www.citiesalliance.org/ca/sites/citiesalliance.org/files/UNH_Guide_Municipal_Finance.pdf.

Soberman, R. (1997a). Rethinking urban transportation: Lessons from Toronto. Transportation Research Record, 1606, 33-39.

Soberman, R. Toronto Transit Commission, (1997b). The track ahead: Organization of the TTC under the new amalgamated city of Toronto.

Soberman, R., Crowley, D., Dalkie, H., Dalton, P., Karakatsanis, S., Levy, D., McCormack, T., \& Vance, J. Residential and Civil Construction Alliance of Ontario, (2006). Transportation challenges in the greater Toronto area.

Sousa, C. Government of Ontario, Ministry of Finance. (2013). A prosperous and fair Ontario: 2013 budget. Statistics Canada. (1981). 1981 Census of Canada census tract boundary files[SHAPEFILE]. Retrieved from http://maps.library.utoronto.ca/cgi-bin/files.pl?idnum=491.

Statistics Canada. (1981) Population, 1981. Retrieved February 2014 from http://dc1.chass.utoronto.ca.myaccess.library.utoronto.ca/census/.

Statistics Canada. (1981). Private Household income - all households - average income. Retrieved February 2014 from http://dc1.chass.utoronto.ca.myaccess.library.utoronto.ca/census/.

Statistics Canada. (2011). Census Tracts - Digital Boundary File (CT-DBF), 2011 Census. Scholars GeoPortal. Retrieved from http://geo2.scholarsportal.info/\#_lang=en\&layersInfo_3187590914_opacity:1 \&order:0;\&BingMapsRoad_op acity:1;;\&basemap=Bing\%20Maps\%20Road\&layers@=3187590914;\&extent_xmin:8864678.686077315\&ymin:5339699.438531706\&xmax:8592562.86538222\&ymax:5523454.054529181\&spatialReference_wkid:102100.

Statistics Canada. (2011) Population, 2011 (v1). Retrieved February 2014 from http://dc1.chass.utoronto.ca.myaccess.library.utoronto.ca/census/.

Statistics Canada. (2011). Total income in 2010 of population aged 15 years and over; Both sexes: Average income \$; Both sexes (v2310). Retrieved February 2014 from http://dc1.chass.utoronto.ca.myaccess.library.utoronto.ca/census/.

Steer Davies Gleave. Metrolinx, (2009). Sheppard-finch LRT benefits case. 
Thompson, S. A. (2012, February 8). Interactive map: The storied history of Toronto's transit plans. The Globe and Mail. Retrieved from http://www.theglobeandmail.com/news/toronto/interactive-map-the-storied-history-oftorontos-transit-plans/article544748/.

Toronto Medical Officer of Health. (2007) Air Pollution Burden of Illness from Traffic in Toronto. Retrieved from http://drivethrulies.files.wordpress.com/2008/07/air-pollution- $\quad$ burden-of-illness.pdf. Toronto Transit Commission. Metropolitan Toronto, (1985a). Network 2011: A rapid transit plan for Toronto.

Toronto Transit Commission. Metropolitan Toronto, Planning Department. (1985b). Eglinton west rapid transit study: Summary report (4.03).

Toronto Transit Commission. (1995). Toronto's rapid transit expansion program. Tunnelling and Underground Space Technology, 10(1), 53-63.

Toronto Transit Commission. Transit City Department, (2010a). Eglinton crosstown LRT.

Toronto Transit Commission. Transit City Department, (2010b). Finch west LRT: Stops and interchange stations.

Toronto Transit Commission. Transit City Department, (2010c). Sheppard east LRT.

Toronto Transit Commission. (2010d). Eglinton crosstown light rail transit; transit project assessment; environmental project report. Retrieved from http://thecrosstown.ca/sites/default/files/pdf/reports/CrosstownLRT-Environmental-Project-Report/appendixn-travel-demand-forecasting-report.pdf.

Toronto Transit Commission. (2013). Milestones. Retrieved from website: http://www.ttc.ca/About_the_TTC/History/Milestones.jsp.

Toronto Transit Commission, \& Metrolinx (n.d.). Eglinton-Scarborough crosstown. Retrieved from http://torontopubliclibrary.typepad.com/.a/6a00e5509ea6a18834017d3c6240cf970c-pi.

Toronto Transit Commission, \& Metrolinx (2010). Scarborough rt. Retrieved from http://www.ttc.ca/images/About_the_TTC/Transit_city/map_Scarborough_RT.jpg.

Transit investment Strategy Advisory Panel. Province of Ontario, (2013). Making the move: Choices and consequences.

VivaNext. (2013, December 5). 'holey' 'moley' tunnelling is complete!. Retrieved from http://vivanext.com/blog/tag/subway/.

Warren, M. (2012, April 9). How to get Toronto's transit policy back on track . The Globe and Mail. Retrieved from http://www.theglobeandmail.com/globe-debate/how-to-get-torontos-transit-policy-back-ontrack/article4223262/.

Woods, M. (2012, February 2). Toronto transit: How to pay for the Sheppard subway. Toronto Star. Retrieved from http://www.thestar.com/news/city_hall/2012/02/02/toronto_transit_how_to_pay_for_the_sheppard_subway.h tml.

Zhao, J., \& Deng, W. (2013). Relationship of walk access distance to rapid rail transit stations with personal characteristics and station context. Journal of urban Planning and development, 139(4), 311-321. doi: 10.1061/(ASCE)UP.1943-5444.0000155. 